Portland State University

PDXScholar

8-1-2017

\title{
Global Intersections: a History of Women's Liberation in Egypt
}

Jordan Earls

Portland State University

Follow this and additional works at: https://pdxscholar.library.pdx.edu/honorstheses Let us know how access to this document benefits you.

\section{Recommended Citation}

Earls, Jordan, "Global Intersections: a History of Women's Liberation in Egypt" (2017). University Honors Theses. Paper 506.

https://doi.org/10.15760/honors.511

This Thesis is brought to you for free and open access. It has been accepted for inclusion in University Honors Theses by an authorized administrator of PDXScholar. Please contact us if we can make this document more accessible: pdxscholar@pdx.edu. 
Global Intersections: A History of Women's Liberation in Egypt

\author{
by \\ Jordan Earls
}

An undergraduate honors thesis submitted in partial fulfillment of the requirements for the degree of

Bachelor of Arts

in

University Honors

and

Social Science

Thesis Adviser

Taghrid Khuri

Portland State University 


\section{Introduction}

The struggle of women against constraints placed upon them because of gender is one historically shared worldwide and continues today. In 1989, Kimberlé Crenshaw coined the term "intersectional feminism" to describe how intersections of oppression impact women to varying degrees and argued that the goal of feminism must be to challenge these intersections. To not challenge these intersections is to, instead, reproduce them. Crenshaw demonstrates that the failure of American feminism to adequately interrogate the problems of racism caused feminism in the US to replicate and reinforce the racism women of color faced. Likewise, civil rights movements to end racism largely ignored the oppression of women by patriarchy and, in so doing, reproduced the subordination of women. The conclusion is that oppression cannot be examined separately; and that, to achieve gender justice, women must actively work towards justice for all. $^{1}$

Similarly, the historic choice by international women's organizations to ignore global intersections caused them to reproduce global oppression. For example, the International Women's Suffrage Association (IWSA) sent two delegates to Egypt between 1911 and 1912. ${ }^{2}$ The objective of the IWSA was to raise international sisterhood in the fight for women's democratic rights. Laura Bier points out that the IWSA initially based its premise for international solidarity among women on biology "and a common experience of exclusion based on that biology". ${ }^{3}$ This basis of sisterhood gave the IWSA the ability to forge sisterhood while simultaneously giving them the impetus to ignore conditions of oppression which could not be

\footnotetext{
${ }^{1}$ Crenshaw, Kimberle. "Demarginalizing the Intersection of Race and Sex: A Black Feminist Critique of Antidiscrimination Doctrine, Feminist Theory and Antiracist Politics." University of Chicago Legal Forum 1989, no. 1.

${ }^{2}$ Badran, Margot. Feminists, Islam, and Nation: Gender and the Making of Modern Egypt. Princeton University Press, 1996, 71.

${ }^{3}$ Bier, Laura. Revolutionary Womanhood: Feminisms, Modernity, and the State in Nasser's Egypt. Stanford University Press, 2011, 162.
} 
universally shared. Thus, though the IWSA wanted to help Egyptian women establish a suffrage association to affiliate with the international branch, its European leaders were unprepared to confront the realities of colonization. How could European women forge international sisterhood on the grounds of women's suffrage with women from states where even men lacked political enfranchisement? It was an uncomfortable question that Western women chose to leave unanswered out of political expediency. After all, challenging the colonial legacy of their governments put them at risk of losing support at home.

Chandra Mohanty points out that women of the non-Western hegemonic world have forged a sisterhood through their common interactions with Western imperialism. Its basis is a shared "opposition to forms of domination that are not only pervasive but systematic." ${ }^{4}$ It is the oppressions which emerged out of the world order through global processes such as colonization and the spread of capitalism that have shaped female identities in the so-called "Second" and "Third World." These terms are used as shorthand, because Mohanty explains that the very idea that there exists a monolithic "Second" or "Third World" is perpetuated by the exploitative structures of the Euro-American capitalist world order. The only shared fact among the countries commonly accepted as belonging to these worlds is a "common context of struggle" against the powers who exploit them and whose very language works to preserve this exploitation. Thus, to create a genuine, worldwide sisterhood, it is imperative for women who belong to these powers to examine how the forces of the patriarchal world order have shaped oppression faced by women of the "Second" and "Third Worlds."

Feminist sociologist Dorothy Smith argues that power, above all else, defines gender inequality. She describes power as "relations of the ruling" and defines it as "a concept that

\footnotetext{
${ }^{4}$ Mohanty, Chandra, "Introduction: Cartographies of Struggle," in Third World Women and the Politics of Feminism, ed. Chandra Mohanty (Bloomington: Indiana University Press, 1991), 4.
} 
grasps power, organization, direction, and regulation [that is] more pervasively structured than can be expressed in traditional concepts provided by the discourses on power." ${ }^{\prime 5}$ Relations of the ruling are wielded in systems and social processes - in law and government, bureaucracies and administrations, in professional organizations and media, but also in the production of thought and ideas, in discourse and identity. Oppression assumes different shapes in different places because of variations in these widescale systems and processes. Smith posits that, therefore, understanding these processes is intrinsic to ending oppression in all forms.

Smith's theory will provide the framework for this examination. While such an examination could be applied to any region or state of what has been deemed the "Second" and "Third World" by the Euro-American hegemonic bloc, the scope of this examination has been confined to Egypt for multiple reasons. First, most emblematic of the separation caused by unexamined intersections is Middle Eastern women. Middle Eastern women have been at the apex of political discourse on the Middle East and Islam with many Westerners pointing to the maltreatment of women in the region on the basis of gender, to justify the maltreatment of those same women on the basis of nationality and religion. This is extremely problematic for feminism and requires rectification. Second, Egypt makes a perfect case for examination of this global intersection Middle Eastern women face, because Egypt's historical struggle against the colonial and post-colonial global orders is rich, while Egypt's history of feminist struggle against both the internal patriarchy and external colonizers is richer still. ${ }^{6}$

\footnotetext{
${ }^{5}$ Smith, Dorothy E. The Everyday World As Problematic: A Feminist Sociology. Northeastern University Press, 1987, 3 .

${ }^{6}$ The Egyptian Feminist Union was founded in 1923, for example, while feminist articulations for education began in the late 1800s across a spectrum of male and female thinkers such as Islamic judge, Qasim Amin; novelist and poet, Aisha Ismat al-Taimuriya; and religious scholar, Shaykh Rifa'i al-Tahatawi. For more on Egypt's rich feminist history, see: Badran, Margot. Feminists, Islam, and Nation: Gender and the Making of Modern Egypt. Princeton University Press, 1995. For more on Egyptian patriarchy, see: Botman, Selma, "Middle Eastern Patirarchy" in Engendering Citizenship in Egypt. Columbia University Press, 1999, 107-115; Kandiyoti, Deniz. "Bargaining With Patriarchy." Gender \& Society 2, no. 3 (September 1, 1988): 274-90; Labidi, Lila. "Islamic Law, Feminism, and
} 
To examine how colonialism and its neocolonial predecessors have influenced women's oppression in Egypt, a historical reading to illustrate how colonialism influenced the development of Egypt's systems of power and social processes, and how those systems and processes oppressed Egyptian women is necessary. Then, a historical examination of how Egyptian women organized to fight these systems and processes will be provided to illustrate the ways in which Egyptian feminist work can be integrated into Western feminist politics. This reading will move linearly through history beginning with Egypt's initial interactions with the colonial world order under Pasha Muhammad 'Ali and the entrance of Egypt into British colonization following the establishment of the Public Debt Commission. Then, the reading will examine the advent of state feminism after the 1952 revolution under Gamal Abdel Nasser and an investigation into the ways in which Nasser's government was a response to both Egypt's historical struggle against colonialism and the emergence of Cold War politics. Finally, the transformation of Egypt under Anwar Sadat and Hosni Mubarak and the complicity of capitalism in exploiting their alacrity for unreserved violence will be explored into present day following the 2011 Arab Spring. However, it is first necessary to decondition the prejudices and assumptions Westerners have been embedded with regarding women in the Middle East.

\section{Demarginalizing Women in the Middle East}

To seriously address the intersections our sisters of the Middle East face, it is of the utmost importance to reject the idea that the oppression women face in the Middle East is unique and that it's produced by Islam or Middle Eastern culture. While Islam has often been invoked to rationalize women's subjugation, many Middle Eastern feminists in fact derive their feminism

Family: The Reformulation of Hudud in Egypt and Tunisia" in From Patriarchy to Empowerment ed. Moghadam, Valentine. Syracuse University Press, 2007, 278-292. 
from their Islamic faiths. ${ }^{7}$ In fact, one of the first Egyptian women elected to their parliament in 1957, Rawya Attiya, commented that she convinced her constituents to vote for her by reminding voters "of the Prophet's wives and families until they changed their opinions." 8

Therefore, such an examination must also reject the sensationalism of Muslim and Middle Eastern women that is often perpetuated by the Western gaze. For this reason, this work abdicates analysis of women's issues in Islam. For example, it specifically rejects debating the contention of female veiling. While two of Egypt's early feminists, Huda Sha'rawi and Saiza Nabarawi, are famous for publicly removing their hijabs at a train station in Cairo, ${ }^{9}$ the matter of veiling is one that ought to be left to the individual feminist. South African-Indian-Muslim author Sa'diyya Shaikh admits that the hijab is forced by law on some Muslim women, such as "Afghani women under Taliban rule." ${ }^{10}$ However, the majority of Muslim women around the world don't live under such circumstances. Shaikh points out that, for some Muslim feminists, wearing the hijab is a political act in protest of "patriarchal prioritization of women's physical and sexual attractiveness." ${ }^{\prime 1}$ In a world where men feel entitled to openly harass women on the streets, for some the hijab reclaims the female body from the male gaze.

Furthermore, the matter of veiling and the so-called "treatment of women by Islam" have time and again been used as justifications to advance imperialist interests. It was used as a justification for the colonization of Egypt by the British Consul General of Egypt, Lord Cromer, who proposed that colonization could liberate Egyptian women, yet simultaneously opposed

\footnotetext{
${ }^{7}$ For a compelling example see: Shaikh, Sa'diyya, "Transforming feminism: Islam, women and gender justice" in Progressive Muslims: On Justice, Gender and Pluralism, ed. Safi, O. Oneworld Publications, 2003.

${ }^{8}$ Sullivan, Earl L. Women in Egyptian Public Life. Syracuse University Press, 1986, 39;

${ }^{9}$ For more, see: Lanfranchi, Sania Sharawi., and King, John Keith. Casting off the Veil the Life of Huda Shaarawi, Egypt's First Feminist. London: I.B.Tauris, 2012.

10 Shaikh, "Transforming Feminism," 152.

11 Shaikh, "Transforming Feminism," 152-153.
} 
women's suffrage in his home country. ${ }^{12}$ It was repeated by George W. Bush as a rationalization for going to war in Iraq. ${ }^{13}$ The treatment of women has even been weaponized as it's been established as "an obstacle to international security and, implicitly, a basis for international intervention" through UN Security Council Resolution $1899 .{ }^{14}$ The matter of female subjugation is political. Narratives lamenting the treatment of Muslim women, while at once suggesting domination of any kind to be the remedy, are a work of these politics. For this reason, this work takes due diligence in not replicating the hegemony of Western cultural ideals on Egyptian feminists. Therefore, the matter of veiling by Egyptian women is left without further discussion. The treatment of women in Islam has been portrayed as uniquely oppressive and dangerous by Western discourse and has provided those who would guise themselves as feminists the impetus to largely ignore female voices that run counter to these portrayals.

The suggestion that the oppression of such an enormous population of women can be separated others is dangerous to all. Women around the world have faced oppression since the dawn of civilization. All of women's grievances are connected and it's of the utmost importance for women to recognize how their various oppressions influence and affect one another. The Western sensationalism of the treatment of women by Islam and Middle Eastern culture, suggests that cases of gendered oppression are due to the cultural traditions and beliefs of the Middle East. This simultaneously infers that oppression faced by women in the West was somehow less abusive than that faced by women of the Middle East, because the oppression of

\footnotetext{
12 Shaikh, "Transforming Feminisms," 150.

${ }^{13}$ George W. Bush's exploitation of women and feminism in justifying the war in Iraq is well documented. For more, see: Cloud, D. L. 2004. "To Veil the Threat of Terror: Afghan Women and the 'Clash of Civilisations' in the Imagery of the U.S. War on Terrorism.” Quarterly Journal of Speech. 90 (3): 285-306; Riley, R. L., C. T. Mohanty, and M. B. Pratt, eds. 2008. Feminism and War: Confronting US Imperialism. London: Zed; Enloe, C. 2010. Nimo's War, Emma's War: Making Feminist Sense of The Iraq War. Berkeley: California University Press; or Pratt, Nicola. "Weaponising Feminism for the "war on Terror", versus Employing Strategic Silence." Critical Studies on Terrorism 6, no. 2 (2013): 327-31.

14 Pratt, Nicola. "Weaponising Feminism for the "war on Terror", versus Employing Strategic Silence." Critical Studies on Terrorism 6, no. 2 (2013): 329.
} 
women in the West wasn't tied to cultural tradition or beliefs. This suggestion allows the erasure of women's rights as a victory of women and women's movements and, instead, claims it as a victory of the very powers which women's rights were won against.

The idea that the oppression of women in the West is not as abusive or as embedded into our culture as the oppression of women from other cultures is a tool systematically used by patriarchists to separate women from each other. Women need each other. Patriarchal governments wrote history, they created a world in which the domination, exploitation, and genocide of people around the world was a divine right of power. Patriarchal structures created a global hierarchy, in which no matter what ring of the ladder one falls under - whether that's white, black, Mexican, Christian, Muslim, Second World, Third World — women always fall to the bottom of their bracket. It is the object of feminism to undo all that patriarchy has done, not to replicate its hierarchal structures, but to create a new structure based on justice, equality, and inclusiveness.

In reality, women of the Ottoman Empire experienced far greater equality than Western women of the time both economically and legally. Early Western literature written by men who stayed with the Ottoman family described the segregation of imperial women within the harem. ${ }^{15}$ These writers often described the female harem as a den of slave concubines present only for the many fetishes of the sultan. What these men failed to recognize, and what other scholars like Professor Leslie P. Pierce have since corrected, is that the harem did not dichotomize Ottoman society into a gendered domain of living, but rather into a class-system. ${ }^{16}$

\footnotetext{
${ }^{15}$ For a notable example, see: Nicolay, Nicolas De, and Washington, Thomas. The Navigations into Turkie. English Experience, Its Record in Early Printed Books Published in Facsimile ; No. 48. Amsterdam, New York: Theatrum Orbis Terrarum; Da Capo Press, 1968.

${ }^{16}$ Pierce, Leslie P. "Beyond Harem Walls: Ottoman Royal Women and the Exercise of Power" in Gendered Domains: Rethinking Public and Private in Women's History: Essays from the Seventh Berkshire Conference on the History of Women. ed. Hell, D.O. \& Reverby, S.M. Cornell University Press, 1992.
} 
The highly privileged were secluded in private from the common spaces of the public. Women and men of the imperial harem both traveled with dense entourages and bodyguards whenever they traveled outside of the harem, usually for public events such as parades. In the public spaces, women and men were very much integrated as could be observed at market bazaars, where working class women and men sold their wares and mingled in the streets. Put simply, the harem was a matter of socioeconomic condition. Furthermore, the female imperial harem was made up of not only concubines, but female relatives of the sultan such as princess daughters, sisters, and queen mothers, but also midwives, administrators, tutors, and servants. ${ }^{17}$

A unique examination of the experience of imperial women's seclusion in the harem was offered by British Lady Mary Wortley Montagu who stayed with the women's imperial harem. In letters that were later published as a book, Lady Montagu depicts a far different illustration than that of her male counterparts who stayed with the male imperial harem and imagined the female harem as a brothel. Lady Montagu wrote that the women of the imperial harem were provided excellent education, comfort, and leisure. They learned to play and write music, arithmetic, and to speak foreign languages. Lady Montagu remarked that the women of the imperial harem were the freest women in the Ottoman Empire, and even added that they were "perhaps freer than any Ladys in the universe." 18

The scholarship which presumes that the imperial harem was a symbol of female subordination also takes for granted that the women in it had no legitimate ability to exercise power or agency. In fact, in the last several hundred years of the Ottoman Empire, imperial

\footnotetext{
17 Pierce, "Beyond Harem Walls," 42.

18 Robert Halsband, ed., The Complete Letters of lady Mary Wortley Montagu, 3 vols. (Oxford: Clarendon Press, 1965-67), 406.
} 
women became the chief political strategists of the sultanate. ${ }^{19}$ Sultan Suleyman I appointed his wife, Hurrem Sultan, as his consulate soon after their marriage around $1520 .{ }^{20}$ As the consulate, she held power in the imperial court, was influential in state matters, and especially in international affairs. ${ }^{21}$ In fact, her rise to power as consulate to the sultan marked the beginning of the era in Ottoman history known as the "Sultanate of Woman."22 What followed during this era was a period where women could rise to power and wealth, not only as concubines and queen mothers, but through administration. Despite being secluded from the outside world, imperial women during this era came to essentially control political power in the empire. ${ }^{23}$

Symbols of female imperial power can be seen in Turkey still today. Since the practice of seclusion was also observed by the sultan, patronage through art and architecture was the primary tool used to extend the sultan's visibility across the empire. ${ }^{24}$ The exercise of patronage through art and architecture by royal women following the reign of Suleyman were demonstrations of their increased power. ${ }^{25}$ Valide sultan Nurbanu not only built her own mosque, the Atik Valide Mosque, but built it within the imperial capital of Istanbul. ${ }^{26}$ Valide Sultan Turhan also demonstrated her power through the construction of a mosque, but more notably commissioned two military strongholds, the Seddulbahir and Kumkale forts, on the

\footnotetext{
${ }^{19}$ For more regarding women and the transformation of political power in the Ottoman Empire, see: Pierce, "Beyond Harem Walls," 45-47.

${ }^{20}$ Yermolenko, Galina. 2005. "Roxolana: "The Greatest Empresse of the East"." Muslim World 95, no. 2: 237.

${ }^{21}$ For example, many scholars attribute the Polish-Ottoman alliance during Suleyman's reign to Hurrem Sultan after two letters from Hurrem to the Polish monarch were discovered; for more, see: Yermolenko, 239-241.

22 Pierce, "Beyond Harem Walls," 40; for more, see: Emeritz, Phillip, "Feminine Power in the Ottoman Harem," in Binghampton Journal of History, Binghampton University, Vol. 14, 2013.

${ }^{23}$ Pierce describes the transformation of power under Suleyman and his predecessors in "Beyond Harem Walls," 45-55; for more see: Peirce, Leslie P. The Imperial Harem: Women and Sovereignty in the Ottoman Empire. Oxford University Press, 1993.

${ }^{24}$ Leslie Peirce, "Gender and Sexual Propriety in Ottoman Royal Women's Patronage," in Women, Patronage, and Self-Representation in Islamic Societies, ed. D. Fairchild Ruggles (New York: State University of New York Press, 2000), 54.

${ }^{25}$ Emeritz, Phillip, "Feminine Power in the Ottoman Harem," in Binghampton Journal of History, Binghampton University, Vol. 14, 2013, 8.

${ }^{26}$ Emeritz, 8 .
} 
Dardanelles strait. ${ }^{27}$ The Dardanelles strait was arguably one of the most important naval passages of the kingdom as it forms a continental boundary between Europe and Asia, connects the Aegean and Mediterranean Seas to the Sea of Marmara, and even allows passage to the Black Sea. The commission of two military strongholds on such a strategically vital naval passage was a remarkable, and intentional, expression of valide sultan Turhan's power, enforcing her image as protector of the empire. ${ }^{28}$

Furthermore, several historians have examined the kadi court registers of the Ottoman Empire in multiple regions to demonstrate that women had a great deal of economic freedom. Ronald Jennings, for example, examined the court records to study the position of women in the rural area of Kayersi. Jennings provided evidence that women enjoyed a certain degree of social equality. They appeared freely in court, sued people, and owned and sold property. ${ }^{29}$ However, due to the rural nature of Kayersi, evidence from Kayersi's work fell short in illustrating the status of women in economic activities outside of property transactions, such as artisanship, trade, and agriculture.

Haim Gerber followed Jenning's work by examining the kadi registers of Bursa, a large, urban commercial center in the Ottoman Empire provided by the Archaeological Museum of Bursa. Gerber found that women in Bursa not only appeared freely in court, sued people, and owned and sold property, but bought property, owned and ran their own businesses, oversaw the administration of their agricultural lands such as vineyards and orchards, invested in commercial

\footnotetext{
${ }^{27}$ Emertiz, 9.

28 Emertiz, 10.

29 Jennings, Ronald C. "Women in Early 17th Century Ottoman Judicial Records: The Sharia Court of Anatolian Kayseri." Journal of the Economic and Social History of the Orient 18, no. 1 (1975): 53-114.
} 
ventures, and owned and worked "in-cottage" artisanal businesses such as wool-making and silkspinning ventures. ${ }^{30}$

Gerber noted that the ability of women to purchase property was the most revealing artifact regarding women's economic status. Previously, scholarship had assumed that women owned property only through inheritance, but multiple court transactions revealed that women, in fact, purchased property freely. Additionally, Gerber examined court records of posthumous estates of women, which revealed that husbands often inherited property from their wives. Gerber also found several cases of women who took out credit from moneylenders for various purposes and even cases of women who made loans to others, including their own husbands. That women in the Middle East had this sort of economic agency as early as the 1600s should not be lost on Western feminists, especially considering that women in America required the permission of their husbands to open bank accounts as recently as the 1960's.

One of the trademarks of the Ottoman Empire was its decentralized millet court system. To easily integrate new territories, the empire provided a certain degree of autonomy to provincial governments by allowing their local, confessional courts to operate concurrently with the Islamic courts. That meant Christian and Judaic communities had their own codes of law and courts to which they could bring all manners of cases, except criminal cases which were tried exclusively in Islamic courts. Marc Baer and Fatma Göçek examined three registers from an Islamic court in Galata from the years 1729, 1769, and 1789. Among their findings, they noted that over time increasing numbers of non-Muslim women brought their cases to the Islamic

\footnotetext{
${ }^{30}$ Gerber, Haim, "Social and Economic Position of Women in an Ottoman City, Bursa, 1600-1700," International Journal of Middle East Studies 12, no. 3 (1980) 231-244.
} 
courts. ${ }^{31}$ They conjectured that this was likely because Islamic law gave women better terms than Christian or Judaic law, especially in cases of inheritance and divorce. At the time, Christian and Judaic law explicitly forbid women from seeking divorce, while Islamic law gave women the ability to seek divorce at least under specified conditions.

With that said, a prominent matter for Egyptian feminists was the issue of family law where patriarchy was most heavily enshrined by making female obedience a matter of law. The fact that the millet system allowed concurrent confessional courts for Christian and Judaic communities is important here, because Christian, Judaic, and Islamic courts observed similar family laws which all made female obedience a matter of legal obligation. Bier points out in her book that the concurrent courts reformed these family laws across confessions as Egyptian women progressed their case for liberation. ${ }^{32}$ This is an important point to remember because it demonstrates that religion had little to do with the enshrinement of female subordination in Egyptian family law. The struggle to reform these laws was not hard-won because any one religion was entrenched in Egyptian culture, but because those who retain power are usually unwilling to relinquish it.

This evidence cannot, and should not, be used to shake the notion of male supremacy in the Middle East. It would be misleading to presume that these facts constituted equality between the genders. Women of the Ottoman Empire very much lived in a world whose boundaries were defined by male orders. Those women who broke boundaries were viewed as a threat. For example, Hurrem Sultan was often regarded as a witch, by both men of the Ottoman Empire and

\footnotetext{
${ }^{31}$ Baer, M. \& Göçek, F. "Social Boundaries of Ottoman Women's Experience in Eighteenth-Century Galata Court Records" in Women in the Ottoman Empire: Middle Eastern women in the early modern era ed. M. Zilfi, Leiden: Brill, 1997.

32 Bier, 105.
} 
men of competing Western monarchies. ${ }^{33}$ Furthermore, the rise of the "Sultanate of Women," is often blamed for the decline of the Ottoman Empire by male scholarship. ${ }^{34}$

However, according to historians of the period, women in the Ottoman Empire did have greater rights to social and economic participation than their European counterparts of the time. Therein lies the quagmire of examining the status of women in the Middle East: It is objectively wrong to suggest that complete gender equality existed or exists in the Middle East. However, it's also objectively wrong to suggest that the gender inequality experienced in the Middle East is unique or caused by religion and culture. Put simply, to be born a woman in basically any part of the world at almost any point in world history has always meant facing forms of gendered violence and oppression. To objectively examine the status of women and the history of women's movements in Egypt, diligence must be taken to remove the lens the Western gaze. That is why in the following examination of Egypt, there will be little attention given to religious orders. While religion does constitute a powerful system in any region, the use of religion to enforce patriarchal values is often because religious orders are exclusively male orders. That was the case in Egypt and the Middle East. Furthermore, their power in Egypt was upheld by patriarchal systems and processes through government, law, and thought production. Thus, it will be these systems and processes that will be the point of investigation.

\section{The Beginning of Colonization in Egypt}

Egypt's struggle against colonial powers began in 1798 when Napoleon Bonaparte attempted to imperialize Egypt under French rule. ${ }^{35}$ Egypt held a strategic waterway via the Suez Canal, which offered passage to British-colonized India from the Mediterranean Sea. France's

${ }^{33}$ Yermolenko, 232-233.

34 Pierce, "Beyond Harem Walls," 41.

${ }^{35}$ Cleveland, William L., and Martin Bunton. A History of the Modern Middle East. Avalon Publishing, 2000, 65. 
occupation of Egypt was thus a threat to Britain's imperial interests. ${ }^{36}$ The Ottoman Empire and Britain joined forces in order to drive Napoleon out of Egypt and declared war in September of 1798. ${ }^{37}$ French forces surrendered by $1801 .{ }^{38}$ Egyptian-born historian Afaf Lufti al-Sayyid Marsot argues that France's three-year occupation was too short lived to leave any real lasting effects on Egypt itself, since the French were never able to assert total control of the region. ${ }^{39}$ Yet, Napoleon's invasion did change the course of Egypt's trajectory as it drew Britain into the global hegemonic struggle of the Middle East, while simultaneously marking the decline of the Ottoman Empire's Mamluk army. ${ }^{40}$

When Pasha Muhammad 'Ali "forced the Ottoman government to appoint him as governor of Egypt in 1805,"41 he both inherited the wider Ottoman struggle against foreign exploitation and initiated a growing autonomy away from the Ottoman Empire. ${ }^{42}$ Pasha 'Ali arrived in Egypt with the Ottoman Mamluks to drive out French forces from the region. ${ }^{43}$ Following his appointment, he embarked on a project towards Egyptian agency. He first eliminated the last vestige of Ottoman control in Egypt by assassinating all members of the Ottoman Mamluk army by $1811 .{ }^{44}$ Then, 'Ali embarked on a series of modernizing reforms to secure Egyptian agency from the Ottoman Empire.

'Ali consolidated power by bringing Egypt's religious center, al-Azhar, under state control. While al-Azhar retained authority of Quranic interpretation and instruction, 'Ali claimed authority of selecting the mufti who was charged with issuing fatwa, or religious rulings, which

${ }^{36}$ Cleveland, 65 .

${ }^{37}$ Cleveland, 66.

${ }^{38}$ Cleveland, 66.

${ }^{39}$ Sayyid-Marsot, Afaf Lutfi. A Short History of Modern Egypt. Cambridge University Press, 1985, 50.

${ }^{40}$ Sayyid-Marsot, 51 and 53, respectively.

${ }^{41}$ Mansel, Phillip. “The Man Who Remade Alexandria.” History Today 60, no. 12 (December 2010): 27.

42 For example, Pasha 'Ali's independence from the Ottoman Empire was so marked that he outright violated Ottoman decrees, such as a decree which forbid the export of wheat. For more, see: Mansel, 27-28.

${ }^{43}$ Mansel, 27.

${ }^{44}$ Mansel, 27. 
essentially brought the religious elite under state-tutelage. ${ }^{45}$ 'Ali also expanded education by establishing a concurrent, secular education system, ${ }^{46}$ while allowing the establishment of private, Western missionary schools in the state. ${ }^{47}$ Furthermore, 'Ali reformed Egypt's legal system to create the Mixed Courts, which were adjudicated by laws modeled after French civil code. ${ }^{48}$ 'Ali also established an independent Egyptian military, served by conscripted soldiers, ${ }^{49}$ and constructed new weapon factories that could produce 1,600 muskets per month by the end of the 1830 s. ${ }^{50} \mathrm{He}$ also ventured to create an Egyptian navy and in 1826 he established a naval school which was instructed by French officers, ${ }^{51}$ built a ship yard in the Alexandrian port, and constructed a naval fleet. ${ }^{52}$

‘Ali's ambitions were, however, costly. Under the Ottoman Empire, landowners collected property taxes and often retained much of the taxes for themselves, which put a drain on state revenue. ${ }^{53}$ 'Ali instituted direct taxation to invigorate the state coffer. 'Ali invested in Egyptian agriculture, ${ }^{54}$ expanded irrigation, ${ }^{55}$ and created an Egyptian export economy in Alexandria all to finance his ambitions for Egyptian agency. ${ }^{56}$ Though 'Ali's irrigation projects were completed

\footnotetext{
45 Badran, Margot. Feminists, Islam, and Nation: Gender and the Making of Modern Egypt. Princeton University Press, 1996, 10.

46 Badran, 10.

47 Badran, 10.

48 Bier, 103.

${ }^{49}$ Cuno, Kenneth M, “Taxation, the monopoly system, and the peasantry” in The Pasha's Peasants : Land, Society, and Economy in Lower Egypt, 1740-1858. Cambridge Middle East Library ; 27. Cambridge [U.K.] ; New York: Cambridge University Press, 1992: 123.

50 Cleveland, 69.

51 Mansel, 29.

52 Cleveland, 69.

53 Cuno, Kenneth M, "Centralization, expansion, and the limits to expansion," in The Pasha's Peasants : Land, Society, and Economy in Lower Egypt, 1740-1858. Cambridge Middle East Library ; 27. Cambridge [U.K.] ; New York: Cambridge University Press, 1992: 103.

54 For more, see: Cuno, “Centralization, expansion, and the limits to expansion," 111-114.

55 For example, 'Ali embarked on a 12-year project from 1822-1834 that installed over 50,000 waterwheels in Lower Egypt. For more, see: Cuno, "Centralization, expansion, and the limits to expansion," 115-116.

56 Cuno, "Centralization, expansion, and the limits to expansion," 104.
} 
with what was essentially slave labor, ${ }^{57}$ and 'Ali's new state military and navy consisted of conscripted soldiers, it was not enough to finance his massive undertakings.

Instead, 'Ali largely financed his endeavors with foreign debt. Thus, an unintended consequence of 'Ali's work was that Egypt's blossoming independence was simultaneously threatened by foreign intrusion. In fact, 'Ali and his predecessors relied so heavily on highinterest, foreign debt to pursue independence and modernization, that by the 1870 s the state required new loans in order to meet its interest payments alone. ${ }^{58}$ By 1876 , Egypt was bankrupt and foreign powers established the Public Debt Commission (PDC), which was charged with collecting the debt by electing a British and French creditor who would, together, control the Egyptian budget. ${ }^{59}$

'Ali's reliance on foreign debt to finance his projects was further complicated by Ottoman-era capitulations, which provided merchants and corporations of foreign countries the ability to conduct business without regulation or taxation by the Egyptian state ${ }^{60}$ Historian Carter Finley argues that ability of European nations to assert economic dominance through commercial capitulations "bears a striking resemblance" to the methods used by capitalist states in free trade agreements. ${ }^{61}$ As shall later be demonstrated, the continuation of the capitulations in Egypt during Egypt's industrialization would have grave consequences for not only workingclass Egyptians, but for Egyptian sovereignty.

The establishment of the PDC over the Egyptian government was a significant loss of autonomy and an insult to Egyptian nationalists' sense of pride. Coupled with the seeming

\footnotetext{
57 In Egypt at the time, the labor was called corvée labor, which Cuno writes "was paid, or was supposed to be." For more, see: Cuno, Kenneth M, "Taxation, the monopoly system, and the peasantry," 122.

58 Cleveland, 99.

59 Cleveland, 98.

${ }^{60}$ For more on the capitulations, see: Kelly, Sean. "Capitulations, Middle East." Encyclopedia of Western Colonialism since 1450, edited by Thomas Benjamin, vol. 1, Macmillan Reference USA, 2007, 177-180.

${ }^{61}$ Kelly, "Capitulations, Middle East," 177.
} 
"Westernization" of Egypt, through the establishment of private, Western missionary schools, new legal codes, an increasing presence of foreign commerce, anti-European tensions inevitably surfaced. A nationalist revolt against the PDC invoked British reaction when it threatened the imperial monarchy's access to the Suez Canal. In 1882, Britain invaded Egypt and inaugurated an occupation that would last for more than 70 years. ${ }^{62}$ Nationalist tensions erupted frequently during those 70 years and provided the foundation for the Egyptian feminist movement to build a female identity around Egyptian nationalism and political activism.

\section{Women in early 20th century Egypt}

While gender was a pervasive point of oppression for all women, class defined women's lives far more than any other distinction did. ${ }^{63}$ While most women across the Ottoman Empire would not have been exposed to the seclusion of the harem, those in the higher economic stratospheres were. For this reason, awareness of a gendered restriction to opportunity first emerged among women of the middle and upper-classes.

Huda Sha'rawi explains in her autobiography, The Harem Years, that she learned alongside her brother from a private tutor as a young girl, but her education stopped when she was married at twelve. ${ }^{64}$ She separated from her husband two years later and embarked on a seven-year period of independence during which she continued her education, able to expand her life "within the parameters allowed by her class and circumstances." ${ }^{95}$ Sha'rawi would go on to create the Egyptian Feminist Union (EFU) and cement herself in history as one of Egypt's most influential early feminists.

\footnotetext{
62 Cleveland, 100.

${ }^{63}$ Badran writes, "Class rather than religion and ethnicity had primarily defined women's social practice and interactions of the sexes." Badran, 33.

${ }^{64}$ Sha'rāwī, Hudá. Harem Years: The Memoirs of an Egyptian Feminist (1879-1924). Feminist Press at CUNY, $1987,17$.

65 Badran, 33.
} 
Like Sha'rawi, Nabawiyah Musa learned from a private tutor alongside her brother. In her personal writings, Musa remembers how she became aware of her secondary status as a girl when her brother continued his education formally in a classroom, but she was required to stay at home. Despite the restrictions placed upon her, Musa taught herself to read and write Arabic, and to perform arithmetic with the books her brother brought home. ${ }^{66}$ Eventually, she applied to the Saniyah School in secret and only coerced consent from her mother to attend the school by threatening to run away. ${ }^{67}$

She would go on to become one of Egypt's first female teachers and the world's first advocates equal pay for women after she discovered that she made less than her male counterparts because she hadn't passed the state baccalaureate examination as the men had. ${ }^{68}$ Of course, women had never been allowed to sit for the examination. Musa applied for the exam and was rebuffed several times, but she persisted and eventually tested in 1907 . Thus, she became the first Egyptian woman to win her baccalaureate diploma and, at the same time, "the first woman teacher to receive a salary equal to male teachers." ${ }^{\prime 6}$ In so doing, Musa helped to set a precedent of equal work for equal pay between women and men in Egypt, a policy which the postindependence government continued to observe. However, education was a privilege of middle and upper-class Egyptian families. Working-class families, men and women alike, often didn't have access to formal education. To spread their feminist awareness, a major preoccupation of early Egyptian women's rights groups was improving access to education.

The British occupation introduced an increasing threat to Egypt's sense of cultural authenticity, while the capitulations marginalized the local Egyptian economy. A growing

\footnotetext{
${ }^{66}$ Badran, 40.

${ }^{67}$ Badran, 41.

${ }^{68}$ Badran, 42.

${ }^{69}$ Badran, 44.
} 
nationalist awareness among Egyptians transformed into what women's liberation advocate, Nawal el-Saadawi, calls "identity politics." She holds that identity politics are "part of the colonial capitalist language." 70 During the colonial period, identity politics transformed under the European production of nationalism, the idea that those who share a common identity should form an individual nationhood. Nationalism was used by world hegemonic powers to undermine the Ottoman Empire by coaxing revolts in Greece and in the Balkans. ${ }^{71}$ Identity politics were two-fold in Egypt. First, there were the politics of Egyptian nationalism and what was determined to be authentically Egyptian. Second, there were the politics of anti-imperialism, the threat of "Westernization," and the corrosion of Egyptian authenticity at the hands of colonizers. Identity politics had dual effects for women. On the one hand, early Egyptian feminists, men and women alike, would advocate for women's liberation in nationalist and anti-Western terms. For example, many Egyptians advocated for opening Egyptian state schools to women on the basis that Egyptian women had historically attended Western missionary schools. ${ }^{72}$ However, identity politics simultaneously allowed patriarchal systems to preserve their power by embedding the subordination of women into nationalist identity. Certain aspects of women's oppression were upheld as an intrinsic part of Egyptian authenticity and those who dared to challenge those aspects were accused of colluding with the colonizers. This meant that while women now attended school, this new-found freedom still had gendered limitations.

Regardless, the emergence of identity politics provided space for Egyptian feminists to make their demands. A male Islamic judge, Qasim Amin, published two papers in 1899 and 1900 which both argued that to liberate Egypt from foreign domination, Egypt had to liberate women

\footnotetext{
70 El Saadawi, Nawal. 2016. "'My identity is not fixed'." New African no. 563: 91.

71 Alan Bodger, "Russia and the End of the Ottoman Empire", in Marian Kent (ed.), Great Powers and the End of the Ottoman Empire (London: Frank Cass, 1996), 81.

72 For more on Egyptian women in private missionary schools see: Cooper, Elizabeth. The Women of Egypt. Hurst \& Blackett, 1914, 165 and 169.
} 
from male domination. ${ }^{73}$ EFU founder Sha'rawi wrote in a 1924 pamphlet, "women are half the nation and the caretakers of future generations, and thus they must be prepared to take up their political and social obligations to the nation. "74 Early women's rights narratives were overwhelmingly tied progress for women to women's roles in relation to men and, therefore, to the nation.

Some early feminists did argue for women's liberation from a human rights standard, such as Zaynab Fawwaz, who advocated for female suffrage in Jaridat al-Nil (Newspaper of the Nile). She wrote, "Woman is a human being as man is, with complete mental faculties and acumen, and equivalent parts, capable of performing according to her own abilities." $" 75$ Regardless of the narrative, an emerging nationalist awareness did create an important possibility for women to make new demands, even if the scope of those demands was limited by patriarchal systems. A nationalist advocacy for female empowerment opened the door for new opportunities to Egyptian women. Women's education by the state began with a women's medical school at Abu Zabal, a military hospital near Cairo. ${ }^{76}$ A girls section at the Abbas Primary School in Cairo was opened in 1895, the Saniyah School which Musa attended was created in 1889, and the Wardiyah Women Teachers' Training School was established in $1916 .{ }^{77}$

The end of the nineteenth century also gave women's voices a new platform through literature and media. Al-Fatah, the Women's Press, was founded in 1892 and promised to "defend the rights of the deprived and draw attention to [their] obligations due."78 It was a new claim on public space for middle and upper-class women, who had once not been permitted to

\footnotetext{
${ }^{73}$ Badran, 62.

${ }^{74}$ Bier, 33.

${ }^{75}$ Badran, 62 and Opening the Gates 223-224.

${ }^{76}$ Badran, 8 .

77 Badran, 9.

${ }^{78}$ Badran, 15.
} 
speak in public. ${ }^{79}$ However, the space claimed was an ideological one in the production of public thought. The divergence of women along class distinctions was important to the early Egyptian feminist movement for three reasons. First, because it was necessary for Egyptian peasant women to work, it appeared that they enjoyed a host of abilities that middle and upper-class women were denied. Egyptian peasant women had claims on public space, they were able to venture out of the home with their faces uncovered and to mingle in the markets with men. ${ }^{80}$ For this reason, to upper-class women particularly, the "peasant woman symbolized freedom." 81 Second, the inability of middle and upper-class women to enter public space due to the tradition of the harem prevented early feminists from spreading their feminist awareness. Finally, a lack of access to education and the more immediate problems they faced due to poverty, impeded Egyptian peasant women from having a real stake in the issue of women's rights.

Early feminists responded to each of these problems through the proliferation of philanthropic organizations. The inheritance rights Muslim women enjoyed enabled them to give charitably. However, philanthropic giving was traditionally performed through donations to religious endowments, called waqfs, which were then administered by a male executor. ${ }^{82}$ Early Egyptian feminists broke from the tradition of giving to waqfs when they created the first female-led philanthropic societies. For example, Sha'rawi founded Mabarrat Muhammad 'Ali in 1909. ${ }^{83}$ Djavidan Hanim, the wife of Khedive 'Abbas Hilmi II, organized an aid operation at Ras al-Tin Palace to help refugees of the Balkan Wars. ${ }^{84}$ In 19191, Jam 'iyat al-Mar'ah al-Jadidah

\footnotetext{
${ }^{79}$ Badran, 92.

${ }^{80}$ Badran, 92.

${ }^{81}$ Badran, 92.

82 Badran, 49.

${ }^{83}$ Badran, 50.

${ }^{84}$ Badran, 51.
} 
(the New Woman Society) was established to educate girls in reading and writing, as well as crafts, which feminists believed could be used as a means to earn money. ${ }^{85}$

Some scholars have critiqued these organizations as an expression of middle and upperclass women's paternalism toward Egyptian peasant women, particularly because some provided training in "domestic science," such as health, hygiene, and child care. ${ }^{86}$ Laura Bier, for example, argues that it was akin to privileged Egyptian women dictating to impoverished Egyptian women what it meant to be good mothers and wives. ${ }^{87}$ Yet, it must be understood that during this period, child mortality rates were high, tuberculosis was rampant, clean water was scarce, water-borne diseases killed many Egyptians with the largest populations being the rural-poor, and a lack of higher education for women meant that most Egyptian women simply didn't see doctors because there weren't female doctors available. ${ }^{88}$ Training in health, hygiene, and child care very literally saved lives. Furthermore, the creation of female-ran charities provided feminists an opportunity to create a communal womanhood. It introduced a new collective role for women as citizens of Egypt, "rather than as members of separate religious communities." 89

Still, the adoption of these narratives tied the justification of women's rights to their roles in the family. Women's education was permitted because it enabled mothers to impress upon their children the values of Egyptian nationalism. This effectively set parameters for reform to women's rights as being inherited through their roles within the nuclear, patriarchal family. Yet women's roles within the nuclear, patriarchal family were problematic for women as the family laws of Egypt legislated female obedience within the family across religious confession. The

\footnotetext{
85 Badran, 51.

86 Badran, 112.

${ }^{87}$ Hatem, Merva. "The Pitfalls of Nationalist Discourses on Citizenship in Egypt." In Gender and Citizenship in the Middle East, ed. Joseph, S. University of Syracuse Press, 2000, 43.

88 Badran, 112. For more on social taboos harming women's health, see: Saadawi, Nawal, "Women and Health in the Arab World," in The Nawal El Saadawi Reader, Zed Books, 1997, 53-64.

89 Badran, 51.
} 
consequence of this narrative was that women's roles, both in the nation and the family, were controlled by patriarchy. Thus, though early Egyptian feminists fought to rewrite the family laws which made female obedience a matter of legal obligation, serious amendment wasn't accomplished until 1979.

Both 'Ali and the British colonizing government were complicit in preserving the oppression of women within the patriarchal, nuclear family. 'Ali established European-modeled civil codes with the Mixed Courts in 1876 and the British occupiers established the National Courts over criminal and commercial disputes in 1883 . However, both governments allowed all matters of family law to remain under the jurisdiction of the millet system. This meant laws regarding marriage, divorce, inheritance, and child custody were adjudicated by concurrent, confessional courts. Bier argues that the failure to modernize laws regarding the family, "Politicized the family [...] as a repository of group identity." 90 Though agriculture, trade, industry, the military, education, and even the legal system modernized, the patriarchal, nuclear family was upheld as a subject outside the purview of state reform.

Family laws enshrined male tyranny across confession. Bier notes that even though Coptic family laws held different beliefs regarding the nature of marriage than Islam, that "contemporaneous changes in Coptic family law mirrored the general trends toward reform in the Muslim personal status laws." ${ }^{\prime 91}$ One such family law was that of bayt al-ta'a, which translates literally to "house of obedience." 92 Women who ran away from their husbands, regardless of the reason, could be returned to her husband by state force. ${ }^{93}$ The law legally bound women to suffer the tyranny of their husbands. Over time, the preservation of such family

\footnotetext{
90 Bier, 104.

91 Bier, 105.

92 Tucker, Judith, Women, Family, and Gender in Islamic Law. New York, Cambridge University Press, $2008: 74$.

93 Badran and Bier both discuss the practice of bayt al-ta' a: Badran, 131-132; Bier, 112-120.
} 
laws enabled patriarchists to claim that female oppression within the family was inherent to Egyptian cultural authenticity. That meant attempts to reform family law could be cast as assaults to the Egyptian nationalist identity.

However, it must be recognized that this kind of legally protected male tyranny within the family was not uniquely Egyptian, or even Middle Eastern. Historian and professor at Georgetown University, Amira Sonbol, details how the doctrine of bayt al-ta'a was in fact modeled after the European doctrine of "coverture." Coverture dictated that, upon being married, a woman lost entirely her individual legal status to her husband. With this loss, her husband could incarcerate her for being disobedient, "enforced by the state through its courts and police." ${ }^{94}$ The disingenuous portrayal of male tyranny within the family as inherent to Egyptian cultural authenticity was truly an exercise of male tyranny over Egypt at large. It was an attempt by patriarchists to maintain power because, once again, those who retain power, are usually unwilling to relinquish it.

\section{The 1919 Revolution}

Egyptian nationalist tensions had been brewing under British occupation decades before the 1919 revolution. In 1911, the Egyptian Nationalist Congress convened in Heliopolis. Women weren't permitted to attend, so Bahithat al-Badiyah wrote a letter articulating the demands of her feminist comrades, addressing both British colonialism and Egyptian patriarchy. Her list of demands for women included equal opportunity to education and work, equal rights to participate in congregational worship, suffrage, and reform of family law. ${ }^{95}$

\footnotetext{
${ }^{94}$ Sonbol, Amira, "The woman follows the nationality of her husband: Guardianship, citizenship and gender," in Hawwa: Journal of Women in the Middle East and the Islamic World, Vol 1, 2003: 112. For more, see: Zaher, Claudia, "When A Woman's Marital Status Determined Her Legal Status: A Research Guide on the Common Law Doctrine of Coverture," in Law Library Journal, Vol. 94:3, 2002, 459-486.

${ }^{95}$ Badran, 69 .
} 
The revolution began in Egypt following the end of World War I, when the Versailles Peace Conference convened in 1919. Egyptian men formed the Wafd Party and its leaders demanded that the British High Commissioner allow their organization to represent Egypt at the conference. ${ }^{96}$ This demand was denied. British authorities arrested the Wafd party's leader, Sa'd Zaghlul. Egyptians responded with strikes in Cairo that soon spread across the nation. ${ }^{97}$

Revolution was brewing and women's participation became instrumental to the nationalist cause.

Upper-class women staged single sex demonstrations while lower-class women rose up in street protests with men. ${ }^{98}$ On March 14th, a woman named Hamidah Khalil became the first woman martyr when she was killed by British police in front of the Husayn Mosque. ${ }^{99}$ Many more women would join her in sacrifice. Together, they became national symbols of the Egyptian struggle. Two days after Khalil's murder, women marched in a procession to mourn Khalil's death. The women “carried flags with crescents and crosses, brandishing the national unity of Muslims and Copts in the face of colonial 'divide and rule."”100 The protest was eventually surrounded and forced to disperse, but the women persisted and held a second demonstration four days later. One British police commander wrote of the significance of women's protests in a letter to his son when he lamented that using force against women invariably put British police "in the wrong." 101 During their occupation, the British conscripted Egyptians and in his later memoirs the same British police commander noted that, "a few

\footnotetext{
${ }^{96}$ Cleveland, 191.

97 Cleveland, 192.

98 Badran, 76.

99 Badran, 75.

100 Badran, 75.

101 Badran, 76.
} 
soldiers became very upset and actually wept" while they were forced to police the protests staged by Egyptian women. ${ }^{102}$

Even Egyptian girls became militant by distributing secret circulars at their schools, an activity that was immeasurably dangerous given the heavy police surveillance of the British colonial government. ${ }^{103}$ In 1920, Egyptian women formed the Lajnat al-Wafd al-Markaziyah lilSayyidat, the Wafdist Women's Central Committee. Badran writes that "when male Wafdist leaders were jailed or exiled, Wafdist women took charge. They maintained contact with Wafdist men, as well as with the British authorities. They handled finances. They kept up morale. They supported workers' strikes, organized boycotts, sold shares in Bank Misr, the new national bank, and collected money and jewelry to finance the cause." 104

In the beginning of 1922, Britain unilaterally issued partial Egyptian independence. Partial, because it was conditioned upon four reservations: continued security of British imperial communications, continued British control of the Egyptian military, continued enforcement of Ottoman-era capitulations, and the partition of the Sudan from Egypt which remained under British colonization. ${ }^{105}$ The continuation of the capitulations enabled the British government to effectively command the Egyptian economy by keeping foreign industry in the region outside of regulation and taxation by the Egyptian state. While other foreign powers took advantage of the privilege afforded by the capitulations, British companies owned large economic stakes within the region. For example, the Suez Canal was and remains Egypt's largest center of commerce since it's the port through which all products are imported and exported. The Suez Canal,

\footnotetext{
102 Badran, 76.

103 Badran, 77.

104 Badran, 81.

105 Cleveland, 193; and Blaustein, Albert P.; Sigler, Jay A.; Beede, Benjamin R., eds. (1977). Independence

Documents of the World. Volume 1. Dobbs Ferry, NY: Oceana Publications. pp. 204-205.
} 
however, was owned and administered by the Suez Canal Company-a British-French enterprise. $^{106}$

Both the women and men's Wafdist parties objected to partial-independence to no avail. Wafdist men conceded when Egyptians were given formal political rights to elect a parliament and write an Egyptian constitution that was finalized by 1923. The constitution of 1923 declared equality among all Egyptians in Article 3. It stated, "[Egyptians] equally enjoy civil and political rights and are equally subjected to duties and public obligations without regard to race, language, or religion." 107 Though the language specifically excluded gender, Articles 74 and 82 provided universal suffrage. Cleveland describes the 1923 constitution as Egypt's most genuine attempt at parliamentary democracy. ${ }^{108}$ However, the extent of democracy was deeply circumscribed by awarding the British-backed monarchy extensive powers, "including the right to appoint the prime minister and [to] dissolve parliament." ${ }^{109}$ King Fuad dismissed parliamentary governments frequently, whenever they challenged his authority. Thus, the Egyptian monarchy existed as a surrogate of British imperial rule as it relied on British support to command the country. ${ }^{110}$

The conclusion of the 1919 revolution was worse for Egyptian women. Three weeks after the constitution's passage, an amendment was passed by the interim government which restricted suffrage and ability to hold public office from women. ${ }^{111}$ Furthermore, Article 32 of the constitution "also declared that [the] fraternity of citizens was the source of all legal and political

\footnotetext{
${ }^{106}$ European Business History Association, “An International Company in Egypt: Suez, 1856-1956 Introduction:” Accessed June 27, 2017 www.ebha.org/ebha2007/pdf/Piquet.pdf+\&cd=1\&hl=en\&ct=clnk\&gl=us.

${ }^{107}$ Egyptian Constitution, Article 3, 1923. Accessed June 27, 2017 http://www.constitutionnet.org/sites/default/files/1923_-_egyptian_constitution_english_1.pdf ${ }^{108}$ Cleveland, 194.

${ }^{109}$ Cleveland, 194.

${ }^{110}$ Cleveland, 194.

${ }^{111}$ Bier, 31; and Badran, 24.
} 
power in the new parliamentary system." ${ }^{112}$ The language provided a gendered definition of citizenship, not a definition which provided different rights and obligations to women and men, but a definition which effectively barred women from citizenship altogether. The participation of Wafd men in the passage of these amendments was a proverbial slap in the face to the women who had organized the revolution while they were behind bars. EFU women parted from the Wafd party. Other women, however, remained and reconstituted themselves as al-Lajnah alSa'diyah lil-Sayyidat (Committee of Sa'dist Women), a group that pledged loyalty to Wafd leader Sa'd Zaghlul. ${ }^{113}$ Thus, there was also a partition between women—feminist nationalists who leaned liberal and Wafd nationalist women who leaned conservative.

\section{Women After the 1919 Revolution}

Following the creation of the 1923 constitution, feminists recalibrated their efforts. The EFU organized itself around a litany of issues: ending the capitulations, ending state-regulated prostitution, creating equal opportunity for women in education and work, obtaining political enfranchisement for women, and reforming Egyptian family laws.

\section{The Capitulations}

The continuation of the capitulations meant that the new Egyptian government could not prevent Europeans from conducting any business, nor could they regulate or tax European enterprise. As the industrial revolution spread around the world, Egypt developed into an export economy of mostly cotton. The common enterprises of the working-class, such as agriculture and artisanship, disappeared over time and manufacturing in European-owned factories became the main source of employment for working-class Egyptians. ${ }^{114}$ The continued enforcement of the capitulations rendered labor laws futile, since labor laws could be applied to Egyptian-owned

\footnotetext{
112 Bier, 31 .

${ }^{113}$ Badran, 88 .

${ }^{114}$ Badran, 194.
} 
businesses only. This included labor laws such as the 1909 law which prohibited factories from employing children under the age of nine. ${ }^{115}$ A lack of labor legislation meant the welfare of Egypt's largely working-class population could not be protected. Furthermore, the industrialization of Egypt and the disappearance of cottage industries, meant that working-class women sank deeper into poverty as manufacturing jobs were reserved primarily for men. ${ }^{116}$

In 1926 the EFU took their fight to the IWSA (regrouped as the International Alliance of Women after European women had won their pursuit of suffrage). They called on the IAW to make a resolution demanding an end to the capitulations. ${ }^{117}$ The IAW passed no such resolution and left the capitulations unaddressed by any resolution until their 1935 congress in Istanbul. Furthermore, the IAW passed the resolution demanding an end to the capitulations only to coerce support from Egyptian feminists on the matter of women's nationality laws. Custom held that women who married foreigners relinquished their own nationality in favor of their husband's. The IAW sought to pass a resolution to reform this practice, however Egyptian feminists maintained that the existence of the capitulations would make such a resolution impossible to lobby in Egypt. ${ }^{118}$ At the time of the 1935 resolution, Egypt was the only country still forced to observe the capitulations. In 1937, the capitulations were formally absolved. ${ }^{119}$

\section{State-Regulated Prostitution}

Under Pasha 'Ali's rule, the Egyptian state banned prostitution from Cairo to Upper Egypt. ${ }^{120}$ However, after British colonization, the state began to regulate prostitution because it

\footnotetext{
${ }^{115}$ Beinin, Joel, "Justice For All: The Struggle for Worker Rights in Egypt," The Solidarity Center, Washington DC, 2010, 5 .

${ }^{116}$ Badran writes that while women worked in factories, they were relegated to "the less skilled and lower paid work," such as spinning in textile factories; Badran, 172.

117 Badran, 200.

118 Badran, 203.

${ }^{119}$ Badran, 204.

${ }^{120}$ Badran, 194.
} 
was unable to prevent European prostitutes from conducting business due to the enforcement of the capitulations. ${ }^{121}$ To dissuade women from prostitution, the Egyptian state imposed new taxes and regulations which, under the capitulations, applied exclusively to Egyptian women. ${ }^{122}$

Since most new employment opportunities were factory jobs reserved for men, prostitution was the most viable work for many working-class Egyptian women. The imperialist dimension of state-licensed prostitution under the capitulations affected Egyptian women in a multitude of ways. Notably, Egyptian prostitutes made far less than their European counterparts, regardless of the taxes imposed upon them. ${ }^{123}$ A free market off of which women's bodies could be profited also meant trafficking of women and young girls through coercion and violence. ${ }^{124}$ Furthermore, Egyptians were expressly barred from joining many of the anti-prostitution organizations operating in the state. For example, the Committee for the Suppression of Traffic in Women and Children forbid membership to Egyptians until 1943. ${ }^{125}$

Egyptian feminists had multiple strategies in ending state-regulated prostitution. Their primary tactic was fighting the capitulations. They also provided women training in incomegenerating activities to encourage women to leave brothels, and even proposed a tax on unmarried men to finance rehabilitative programs for former-prostitutes. ${ }^{126}$ Feminists also wrote to Islamic leaders for support and though Shaykh al-Azhar praised their efforts, he "did not push the issue politically."127 The religious establishment would mobilize against women's education

\footnotetext{
121 Badran, 193 and 195.

122 Badran, 194.

123 Badran, 195.

124 Badran, 197; Badran sites feminist Bertha Pappenheim who investigated sex-trafficking in Alexandria and recorded girls as young as six who had been abducted and forced into prostitution; for more, see: Pappenheim, Bertha, Sisyphus Arbeit: Reisebrief aus den Jaren 1911 und 1912, Verlag Paul E. Linder, 1924.

125 Badran, 200.

126 Badran, 205.

127 Badran, 198.
} 
on the grounds that it jeopardized women's sexual purity, yet never formally challenged prostitution.

Although the capitulations ended in 1937, state-regulated prostitution continued. In 1939 the Ministry of Social Affairs was created and charged with regulating licensed houses of prostitution. ${ }^{128}$ Its new deputy minister, 'Abd al-Mu'min Riyad, said that the matter of stateregulated prostitution required a "gradual approach."129 Ten years after the creation of the Ministry of Social Affairs, state-licensing for prostitution ended. However, only in 1953 was prostitution completely outlawed. ${ }^{130}$

\section{Expanding Women's Education and Work}

Following the 1919 revolution, the EFU continued its fight for female education.

However, the class-structures of Egyptian society permeated the feminist struggle. Badran writes that, "upper-class girls were kept out of the ordinary state schools by their families and rarely attended university until after the 1952 revolution."131 The EFU formulated its support of female education in nationalist terms by arguing that women's education was "the key to restoring national greatness." 132 Feminists called upon the state to use state-provided education to instill nationalist sentiment in Egyptians. For example, after teaching under the British-colonial school system, Nabawiyyah Musa lamented that it offered Egyptian students un-Egyptian curriculum. She wrote, "Our children would acquire a sense of nationalism from their Egyptian teachers that they do not get from foreign teachers."133

\footnotetext{
128 Badran, 205.

129 Badran, 205.

130 Badran, 206.

131 Badran, 142.

132 Badran, 145.

133 Badran, 146; for more, see: Musa, Nabawiyah, "Egypt's Need for Women Doctors, Teachers, Dressmakers, and Other Professions," in The Woman and Work, 1920. (It should be noted that Badran translated the chapter and book titles to English, but the work has yet to be officially translated in whole.)
} 
Nationalist narratives for women's education helped the EFU to successfully lobby the state to open secondary schools for girls not only in cities like Cairo, but in provinces like Asyut, Tanta, and Mansurah. ${ }^{134}$ In order to assuage upper-class families to send their daughters to school, the state also opened two elite schools. ${ }^{135}$ Enrollment of women in secondary schools tripled between 1925 and $1935 .{ }^{136}$ Women also exceeded their male counterparts in school performance. In 1930, 57.7 percent of girls who sat for the baccalaureate examination and 52.9 percent of girls who sat for the primary school examination passed, while only 47.5 and 43.3 percent of boys passed the same exams, respectively. ${ }^{137}$

Yet, gendered narratives regarding women's education persevered. For example, conservative voices protested that women's higher education failed to inculcate them with a sense of the "woman's duty." 138 The Ministry of Education responded by opening schools dedicated to educating women on motherhood and domestic sciences the following year. ${ }^{139}$ Additionally, conservatives worried that desegregation through women's education would lead to moral degradation. The two elite schools opened for upper-class women adhered to strict segregation rules to the extent that male teachers and servants were forbidden. ${ }^{140}$ When a reactionary conservative, Isma'il Sidqi, rose to power, he closed university education to women, arguing that "it is repugnant for us to see young women students enter into contact with the male students." ${ }^{" 141}$ However, women's education persisted after the regime fell in 1933.

\footnotetext{
134 Badran, 143.

135 Badran, 143.

136 Bier, 194.

137 Badran, 147.

${ }^{138} \mathrm{Na}$ 'imah al-Ayyubi, for example, called for courses in child care and home economics to be "added to the standard syllabus in girls schools." Badran, 147. For more, see: al-Ayyubi, Na'imah, "An Opinion on the Education of the Girls in Egypt," in al-Misriyah, May 1, 1937, 18-21.

139 Badran, 147.

140 Badran, 143.

${ }^{141}$ Badran, 161-162.
} 
While female education expanded significantly during the interwar period, work for women was a different breed of challenge. Badran surmises that this was because "work for middle-class women constituted a far more threatening challenge to middle-class patriarchal culture than did education." ${ }^{142}$ School curriculum could be formulated to fit within the boundaries of prescribed female domesticity, while employment for women could not. Women's work also reduced female dependency upon husbands and family patriarchs for economic support. Additionally, it challenged the male monopoly of the workplace. Under the economic duress caused by the capitulations, the Egyptian male order vehemently opposed additional competition for employment that women's work imposed. Egyptian men argued that women should not be allowed to work in jobs that would, otherwise, go to men while also insisting that women's employment would not only cause neglect towards women's familial roles, but lead to their moral degradation. ${ }^{143}$

In 1933, the Egyptian parliament passed new labor laws regulating women's role in the workplace. The staple of these new labor laws was Article 10, which enumerated types of work forbidden to women. Badran writes, "This included labor considered physically taxing or dangerous, such as working in mines or foundries, manufacturing explosives, coating mirrors with mercury, and handling lead." ${ }^{144}$ The narrative that work could lead to women's moral degradation was enshrined in Article 10 by prohibiting any work that included handling alcohol and slaughtering animals. Women were also forbidden from operating or supervising the operation of machinery, but were, however, allowed to clean it. This "[regulated] them to the less technologically advanced sector of production." ${ }^{145}$ Other parts of the law were intended to

\footnotetext{
142 Badran, 165.

143 Badran, 168.

144 Badran, 174.

${ }^{145}$ Badran, 174.
} 
control exploitation of women in the workplace by requiring them to receive an hour of rest during each working day. ${ }^{146}$

Bier argues that the labor laws of 1933 and the EFU's participation in crafting them are exemplary of the EFU's paternalistic role toward the working-class women of Egypt. She writes that early Egyptian feminists "accepted the paternalism of liberal-nationalism, in part because it gave them authority [...] to perform public work so that they could instruct working-class and rural women how to become proper citizens." 147 Middle and upper-class women were the first patrons of expanded rights to women's education and work. The 1930s labor laws demonstrated the EFU's concerns for issues that plagued working-class women like low pay, long hours, and lack of legal protections. However, it also conceptualized the Egyptian working-class woman as distinct from the Egyptian working-class man, with different rights, responsibilities, and obligations owed.

Though working-class women found opportunities to work deeply circumscribed during the interwar period, those armed with higher educations, namely middle and upper-class women, found the period more favorable. Women began their careers as doctors in the early 1930s, which faced little popular objection since female doctors could perform needed services without precipitating any questions of modesty or sexual purity. ${ }^{148}$ The first woman to enter the Egyptian bar was admitted in 1933. ${ }^{149}$ Prior to her admittance, one Egyptian cleric "declared that women must not practice law because their voices should not be heard in public," a theory which feminists argued against by pointing out that women gave testimony in court. ${ }^{150}$

\footnotetext{
${ }^{146}$ Badran, 174.

147 Bier, 33.

148 Badran, 180.

149 Badran, 183.

${ }^{150}$ Badran, 182 .
} 
Thus, Bier's argument offers a degree of nuance. The 1933 labor laws, which forbid women from various jobs, had relatively little impact on middle and upper-class women since they didn't seek industry-based work. At the same time, the 1933 labor laws written to protect women implicitly recognized the exploitation working-class Egyptians faced. Yet, only women and children necessitated legal protection. Even then, the 1933 labor laws aiming to protect women and children would remain difficult to enforce until the revocation of the capitulations in 1937. Therein rests the quandary of intersections: the activists caught between them are divided between which oppressions to address. On the one hand, women faced interpersonal gendered oppression both intimately in the home and publicly in Egypt at large. On the other hand, working-class Egyptians faced oppression through workplace exploitation as the world over did during the industrial revolution. However, Egypt further faced the challenge of being crushed under an international system, which prevented them from making any serious progress with regards to their personal welfare or the welfare of their nation and its future. The assumption that such moves on part of the EFU are due to a sense of elitism, should be cautioned against. Perhaps the mistake for Egyptian feminists wasn't a realized complicity in replicating systems of oppression, but an understood bargain made with those systems to achieve their feminist agenda little by little. However, that bargain produced unintended consequences for poor women in Egypt. Unfortunately, those consequences would not be confined to women's work.

\section{Political Enfranchisement}

After political enfranchisement was restricted from Egyptian women following the amendment to the 1923 constitution, women were further forbidden from attending the opening ceremonies of the new parliament. Egyptian women protested by holding their own mock elections; their votes gave 77 seats to the Liberal Constitutionalist Party and only 12 seats to the 
Wafd who had prevailed in the all-male elections. ${ }^{151}$ Though women were barred from attending the opening ceremony, that same day the EFU and WWCC presented their demand for women's suffrage at the gates of parliament. ${ }^{152}$

Following that, the EFU took "a piecemeal approach to gaining political rights [by suggesting] that the vote might be restricted to women of property or education," which some have blasted as an injustice, particularly because illiterate and unpropertied men could vote. ${ }^{153}$ However, the EFU then turned its social service programs towards helping women meet the standard for obtaining the women's political rights they advocated for, although it must be emphasized that women still had no political rights. Journalist and EFU member Saiza Nabarawi said, "For the moment the activity of the EFU is directed above all to make the masses aware of the rights of the woman [and] to prepare [them] little by little for the idea of suffrage."154 Overall, however, the matter of women's suffrage took a rather peripheral seat in the EFU's platform throughout the decade which followed the revolution. They advocated harder and far more loudly for women's education, work, and reform of the family laws. Presumably, they believed doing so would eventually make women's suffrage inevitable.

That changed when Sidqi rose to power. His conservative, reactionary government suspended parliament and effectively rendered the Egyptian constitution obsolete. ${ }^{155}$ Outrage spread across the country when Sidqi suggested that free elections could be held, regardless. Egyptian women came together across party lines to form a coalition that staged demonstrations

\footnotetext{
151 Badran, 208.

152 Badran, 209.

153 Badran, 209.

154 Badran, 209; for more, see: Nabarawi, Saiza, "Evolution of Feminism in Egypt," in L'Egyptienne, March 1925, 46-47.

155 Badran, 210.
} 
and urged men to boycott the elections. ${ }^{156}$ Once more, Egyptian feminists rose up to defend their nation. Furthermore, women were arrested during protests for the first time in Egyptian history. Nabarawi wrote, "For the first time in our history, women were imprisoned for a political question. This inaugurates a glorious page in Egyptian feminism." ${ }^{157}$ By September 1933, Sidqi had been overthrown and the matter of women's suffrage was, once again, placed centerstage of Egyptian feminist politics.

The EFU presented the case for women's suffrage in Egypt at the following IAW congress in Istanbul and pressed successive governments like that of Prime Minister 'Ali Mahir in 1936 and Mustafa Nahhas in 1937 and 1942, though both appeals proved unsuccessful. ${ }^{158}$ Feminists also harnessed the power of the women's press by publishing articles. Nabarawi submitted a piece to an essay contest sponsored by Prime Minister 'Ali Mahir titled "The Feminist Evolution and the Benefits That Accrue to the Public Well-Being." The essay won firstplace, and yet won no action by Mahir's government. ${ }^{159}$ In 1936, the Egyptian government signed the Anglo-Egyptian Treaty, which provided permanent occupation of British troops in the Suez Canal Zone. This intensified Egyptian women's demands for political rights. ${ }^{160}$ Feminists like Sha'rawi appealed to women directly by distributing leaflets in Arabic and French that said, "Yes, you have the right and what is more the duty, before the ratification of a treaty, to call for a referendum addressed to all the citizens of Egypt (men and women) permitting them to judge and express freely their views and wishes."161

\footnotetext{
${ }^{156}$ Badran, 210.

${ }^{157}$ Badran, 210; for more, see: Nabarawi, Saiza, "The Women in the National Movement," in L'Egyptienne, May 1931, 28.

158 Badran, 212-214.

159 Badran, 214.

160 Badran, 214-215.

${ }^{161}$ Badran, 214; for more, see: "Stand women, stand dead!" in L'Egyptienne, October 1936, 2-3.
} 
Following the 1936 treaty, feminist organizations consolidated to maximize their mobilization for women's suffrage. A founder of the Wafd Party's first women's periodical alAmal, Munirah Thabit, published an article in the EFU-founded al-Misriyah that demanded women's equal political rights. ${ }^{162}$ As mentioned, EFU and Wafd women parted ways following the 1923 constitution. The choice of conservative-leaning Wafd women and liberal-leaning EFU women to combine their efforts, despite their differences, is a testament to the importance that women's political enfranchisement took across ideological lines. Feminists directly challenged male politicians by asking for their stance on women's suffrage and, soon, politicians publicly voiced their support for equal voting rights. ${ }^{163}$ However, their support stopped short of bringing any legislation of consequence to parliament.

What is probably the most remarkable outcome of the Egyptian feminist movement, was the formation of the Arab Feminist Union. It was one of the first markers of what would become the pan-Arab movement. As women in Egypt amassed in support of universal suffrage across party-lines, the EFU organized the first Arab Feminist Conference, at which Sha'rawi and other feminists argued for, not only Egyptian women's voting rights, but all Arab women's voting rights. ${ }^{164}$ Egyptian men and women at the conference argued that patriarchal politics enabled men to legislate for men's interests exclusively. ${ }^{165}$ The transformative power of Arab-unity would be harnessed by future leaders, most notably in Egypt under Gamal Abdel Nasser following the 1952 revolution. Unfortunately, despite decades of organization and advocation, Egyptian women wouldn't receive the right to vote and to hold public office until the revolutionary constitution of 1953 .

\footnotetext{
162 Badran, 215.

${ }^{163}$ For example, Majd al-Din Sa'fan, Muhammad Husayn Haykal, and Hafiz 'Afifi all publicly declared their support for women's suffrage. For more, see: Badran, 215-216.

164 Badran, 216-217.

${ }^{165}$ Badran, 217.
} 


\section{Reforming Egyptian Family Laws}

The family laws of Egypt enshrined women's gendered roles and patriarchal power within the family. Most exemplary of this was the practice of bayt al-ta'ah. It must be remembered, that these sorts of family laws were not exclusively Islamic, and the other concurrent confessional courts in the region observed the same types of laws. In fact, one supporter of $t a$ ' $a$, Ali 'Abd al-Wahid, argued that there was nothing "unique to Islamic law about the principle of obedience: it was also a guiding principle of marriage as a moral and legal institution in civilized countries generally." ${ }^{166} \mathrm{He}$ went on to make example of husbands in France who, because they were responsible for the financial well-being of their wives, were entitled to their obedience.

Egyptian feminists contended to reform "patriarchal excesses," but what they regarded as excess, many men regarded as their inalienable rights. ${ }^{167}$ Egyptian feminists were forced to negotiate their advocacy for a reform of patriarchal excess without fundamentally challenging the gendered roles envisioned by the family laws. Rather than challenging the idea that women owed obedience to their husbands, for example, they argued that such obedience had to be derived from consent. ${ }^{168}$ On the one hand, challenging these gendered roles directly meant challenging national identity politics. Egyptian feminism was directly rooted in nationalism; dividing themselves from their national identities risked undermining the feminist movement. On the other hand, not challenging them would go on to impede feminists by embedding the idea that women had inherently gendered roles to perform into nationalist discourse on women.

The family laws Egyptian feminists sought to reform were multiple: establishing a minimum marriage age, extending a mother's legal custody of her children, abolishing bayt al-

\footnotetext{
166 Bier, 118 .

${ }^{167}$ Badran, 125.

${ }^{168}$ Bier, 113.
} 
ta' $a$, restricting polygamy, and regulating divorce claims made by men. The EFU successfully campaigned to have the marriage age for girls set at sixteen in 1923, although "the state itself was negligent" in regulating this law and often the law was outright ignored. ${ }^{169}$ In Egypt, "mothers retained custody of daughters until the age of nine and sons until the age of seven," which the EFU successfully campaigned to have the ages increased by two years each. ${ }^{170}$ The EFU campaigned against bayt al-ta'ah by insisting that it was an overreach of male authority and that a wife's obedience had to be derived through consent. Yet, the practice wasn't ended until 1967. ${ }^{171}$ The EFU advocated for a restriction of polygamy and demanded that "a man be permitted to take a second wife only if his first wife were sterile or had an incurable illness." 172 Parliament passed a draft proposal to restrict polygamy, but the king vetoed it in $1927 .{ }^{173}$

Under Egyptian family laws, women and men both had rights to seek divorce. However, a woman's ability to do so was heavily conditioned, whereas "a man could repudiate his wife simply by pronouncing a formula in her presence or absence, with no witnesses, and at any time or place." 174 Rather than focusing on providing women greater freedom to seek divorce on their terms, the EFU campaigned to restrict divorce for men "for serious reasons only, and only in the presence of a qadi." ${ }^{\prime 15}$ The 1929 revised law codes reformed divorce law only by invalidating male divorce pronunciations made while intoxicated and conditioned women's ability to seek divorce on grounds of extreme harm, such as "the disappearance of a husband for four years."

\footnotetext{
169 Badran, 128.

170 Badran, 132-133.

171 Badran, 131-132.

172 Badran, 128.

173 Badran, 130.

174 Badran, 130.

175 Badran, 131.

176 Badran, 131.
} 
Feminists called upon the state to protect women from male tyranny, rather than challenge the patriarchal structures of the family which permitted male tyranny altogether. When the British-backed monarchy was overthrown in 1952, the revolutionary government formulated its political ideologies around Egypt's patriarchal nationalism. The revolutionary government would go on to universalize suffrage, expand women's education and employment, and even allow women to hold public office. Yet, its patriarchal ideologies permeated the lives of women, even as it purported to progress the feminist agenda.

\section{The Rise of Gamal Abdel Nasser}

In 1952, the Egyptian monarchy was overthrown in a revolt led by a group of young military officers known as the Free Officers Movement. The rise of the Free Officers and their leader, Gamal Abdel Nasser, can be attributed to the nationalist campaign for total liberation from British colonization. The objective of the revolutionary government was the development of Egypt which, the Free Officers held, had been stifled under colonization. ${ }^{177}$ There were two major evolutions in the Egyptian political system with the rise of Nasser. First, the state emerged "as the arbiter of public order [and] the agent of social reform." 178 Second, the emergence of the Cold War situated Egypt in the middle of an increasingly antagonistic struggle for world hegemony. ${ }^{179}$

The continued presence of British troops and economic depression created violent instability in Egypt. By the late 1940s, university students organized anti-British demonstrations and some militant Egyptians embarked "in a systematic campaign of violence against foreigners, foreign business establishments, and Egyptian officials regarded as accomplices of

\footnotetext{
177 Abou-El-Fadl, Reem "Neutralism Made Positive: Egyptian Anti-Colonialism on the Road to Bandung," in British Journal of Middle Eastern Studies, 42:2, (2015), 221. For more, see: Simon Bromley, Rethinking Middle East Politics: State Formation and Development (Oxford: Polity, 1994).

178 Bier, 35.

${ }^{179}$ Abou-El-Fadl, 220.
} 
imperialism.." ${ }^{180}$ Skirmishes between Egyptian guerrillas and British armies erupted, and an Egyptian police station was destroyed by British tanks, resulting in the death of fifty Egyptian police officers. ${ }^{181}$ This led to riots in Cairo, known as Black Saturday, and then a military coup on July 23, 1952 led by Nasser and the Free Officers. ${ }^{182}$

The Free Officers Movement was organized around a six-point program including "the destruction of British colonialism and the removal of its Egyptian collaborators, the elimination of feudalism, the ending of the political control of the state by foreign capital, the establishment of social justice, the formation of a strong national army, and the creation of a healthy democratic life." 183 The execution of the six-point program was conflicting in nature. The objective of national autonomy through the abolition of foreign influence risked impeding development projects and, especially, the creation of a strong Egyptian army. Nasser had to finance his government, which "had to be premised on foreign assistance," 184 and yet couldn't compromise the sovereignty of the new regime.

These two conflicting goals of national sovereignty and national development had the potential to force Nasser's hand in conceding to various demands of the Western hegemonic powers. Of course, those powers attempted to bend Nasser to their will. For example, at the behest of the British government who negotiated with Nasser from 1952-1954, the U.S. refused to provide Egypt financial assistance in order to not increase Nasser's leverage. ${ }^{185}$ However, the emergence of the Cold War enabled Nasser to navigate this conflict by formulating a policy of non-alignment. The policy of neutrality allowed Nasser "to maintain prospects for cooperation"

\footnotetext{
180 Cleveland, 294.

181 Cleveland, 295.

182 Cleveland, 295.

183 Cleveland, 296.

184 Abou-El-Fadl, 223.

185 Abou-El-Fadl, 224-225 and Heikal, Muhammad H., Cutting the Lion's Tail: Suez Through Egyptian Eyes, London, Corgi, 1988, 47.
} 
with both the Soviets and the U.S. ${ }^{186}$ Nasser refused to cement any permanent relations with either side without first securing total independence. ${ }^{187}$ This strategy ultimately secured a final purge of British troops from the Suez Canal in October 1954.

Nasser embarked on a series of reforms, beginning with the land reforms of 1952 which placed a cap on land ownership and redistributed land from wealthy landowners to Egyptian peasants. ${ }^{188}$ In November 1953, Nasser issued a decree reclaiming the wealth and property of the royal family of Pasha 'Ali ${ }^{189}$ and appropriated the funds to building new schools and healthcare centers in rural Egypt. ${ }^{190}$ A new constitution provided for a 350-member national assembly and included a bill of rights which "protected Egyptians from discrimination on the grounds of race, sex, language, or religion." 191 The adoption of the 1956 constitution enfranchised women politically and created new opportunities to education and work. However, to complete its reforms, Nasser also undertook a campaign to consolidate power. ${ }^{192}$ It was Egypt's first flirtation with homegrown despotism.

To this extent, the officers abolished political parties and established the Liberation Rally, a party that "was not a party in the parliamentary sense of the term but rather a vehicle through which the regime marshaled support for itself and gained control of such interest groups as students and workers." ${ }^{193}$ Nasser's movement thus transformed from a military-led coup into a

\footnotetext{
186 Abou-El-Fadl, 225.

187 For example, Nasser sent a message to U.S. Secretary of State John Dulles stating, "We may see our future lying with the West, but this is something that can only be said openly by a truly independent Egypt." For more, see: Heikal, 53.

188 Waterbury, John, The Egypt of Nasser and Sadat: The Political Economy of Two Regimes, Princeton University Press, 1983, 61.

189 CCR Decree, 8 November 1953, http://nasser.org/Decisions/DECcontent.aspx?src=Searchlang=ar.

190 Amin, Galal A., "Evolution and Shifts in Egypt's Economic Policies: In Search of a Pattern," in

Developmentalism and Beyond: Society and Politics in Egypt and Turkey ed. Ibrahim, S., Keyder, C., and Oncu, A. American University in Cairo Press, 1994, 122.

191 Cleveland, 299.

192 Cleveland, 297.

193 Cleveland, 298.
} 
populist, authoritarian republic and soon took to executing members of rival organizations. ${ }^{194}$ Over time, Nasser's tyranny grew. He endeavored on a pattern of criminalizing not only opposition, but dissent to any degree. For example, in 1954 Nasser ordered a worker strike at a large textile plant near Alexandria to be put down and executed its leaders. ${ }^{195}$ The regime enforced the illusion of a liberated Egypt, while at once suffocating the tenants of democracy.

To galvanize support, Nasser formed a new Egyptian nationalist identity in pan-Arabism. He did this in the preliminary period of the regime with "the establishment of pan-Arab media, such as the influential radio station Sawt al-'Arab," which was broadcast not only in Egypt, but across the Middle East. ${ }^{196}$ In the era of a transforming world order which introduced increased hostility between Western powers and the Middle East, pan-Arabism had "popular resonance."197 A state-sponsored publication, The Egyptian Revolution in Three Years, recognized the potential of pan-Arabism to transform the basis of nation-building in the Middle East. The Revolution aimed "to disseminate joint Arab heritage so that the Arabs [could] build a united front."198 In this sense, identity politics came to play a large role in the legitimization of the Nasserist regime. Abou-El-Fadl writes that, "Egyptian students were coached in al-mawad al-qawmiyya, or Arab National Subjects, which cultivated 'a strong sense of identification and pride with Arabism, anti-colonialism and nationalist leaders of Nasser's caliber.'",199

The ouster of Britain from Egypt brought an end to the global imperial system. However, the emergence of Cold War politics transformed that system into "a more far-reaching concept,

\footnotetext{
${ }^{194}$ For example, six leaders of the Muslim Brotherhood were executed in 1954; Cleveland, 298.

195 Cleveland, 298.

196 Abou-El-Fadl, 227.

197 Abou-El-Fadl, 230.

198 State Information Service, Al-Thawra al-Misriyya fi Thalath Sanawat, Services Council Press, $1955,179$.

199 Abou-El-Fadl, 231; Faksh, Mahmud "The Consequences of the Introduction and Spread of Modern Education: Education and National Integration in Egypt," in Middle Eastern Studies, 16:2, May 1980, 52.
} 
encompassing American defense plans and all who participated in them." ${ }^{200}$ Egyptian activist, author, and nurse, Nawal el-Saadawi, argues that the globalization of capitalism introduced a "New World Order" that "in fact is an old world order which uses new methods of exploitation and domination, both economic and intellectual." ${ }^{201}$ The Free Officers regime recognized the transformation of imperial designs through Cold War politics. 'Abd al-Hamid Saud, the Egyptian representative of Karachi, lambasted the U.S. over the conditions the American government tied to offers of foreign aid. Saud said, "Having destroyed the shackles we suffered [...] do you expect us to put them around our necks once again, voluntarily and by choice?"202

Nasser refused to join Egypt into any such alliance as he believed it to be "an extension of imperialism." ${ }^{203}$ His public defiance of Western systems through non-alignment garnered support from the Arab world, legitimizing the Free Officer's attempts to organize Arab identity politics into Egyptian nationalism and propelling Nasser "into regional prominence."204 However, Nasser's defiance of America's attempts to control the new world order also made him ineligible for U.S. military support.

In 1955, Nasser concluded the Czech arms deal, which provided Egypt "\$200 million worth of advanced Soviet military equipment in exchange for Egyptian cotton." ${ }^{205}$ The deal was lauded by the Arab press and viewed across the Arab world as a successful assertion of independence from Western imperial designs. In response, the U.S. withdrew a loan offer for a massive development project, the Aswan Dam. To finance this project, Nasser instead embarked on a program he and the Free Officers termed, “Arab Socialism." In fact, Arab Socialism was

\footnotetext{
200 Abou-El-Fadl, 239.

${ }^{201}$ El-Saadawi, "Women and the Poor," 78.

202 ENA: Egyptian Embassy, Karachi to Egyptian Foreign Ministry, No. 56, 12 October 1955.

${ }^{203}$ Cleveland, 301.

${ }^{204}$ Cleveland, 301.

${ }^{205}$ Cleveland, 302.
} 
less a form of Marxist socialism and "more a form of state capitalism," not endeavored on the basis of class conflict, but "based on the need to raise money." ${ }^{206}$ Arab Socialism soon became another grip of the regime's authoritarian rule: both foreign-owned and domestic enterprises were brought under state control, including banks, insurance companies, import agencies, and hotels. Perhaps most dangerously, Arab Socialism predicated the seizure of the press into state control and censorship. ${ }^{207}$

The Nasserist regime was delicately balanced on its ability to mobilize popular support despite its strict and often violent authoritarianism. To strike this balance, the Nasserist regime was cautious of challenging the long-standing interpersonal power structures, specifically those formed by Egypt's patriarchal family system. Despite providing women political enfranchisement and new opportunities to education and work, the Nasser regime refused to take any action which might alter the patriarchal dynamics of Egyptian private life.

\section{Women and State Feminism in Nasser's Egypt}

Since the Nasser regime claimed sole authority over social reform, independent feminist movements were co-opted by the government into what professor and author Mervat Hatem describes as "state feminism." ${ }^{208}$ While women were agents of new opportunities to political enfranchisement, education, and work, independent feminist voices were forcefully silenced with imprisonment. The 1956 revolutionary constitution provided women the right to vote and equal opportunities to education and work by banning gender-based discrimination. ${ }^{209}$ Yet these gains for women were not granted due to a female-inclusive ideology among the all-male military bureaucrats of the Nasser regime. In 1954, for example, the Constitutional Assembly convened

\footnotetext{
${ }^{206}$ Cleveland, 308.

207 Cleveland, 308.

${ }^{208}$ Hatem, Mervat, "Economic and Political Liberation in Egypt and the Demise of State Feminism," in International Journal of Middle East Studies, 24:2, 1992, 231-251.

${ }^{209}$ Hatem, "Economic and Political Liberation," 232.
} 
without female representation. ${ }^{210}$ Arguably, women's suffrage was provided out of political expediency to generate popular support. In fact, women's political enfranchisement was obliged only after rumors that the 1956 constitution would not provide women's suffrage sparked protests from even moderate women. ${ }^{211}$

New educational and economic opportunities for women were viewed as a "means of achieving economic modernization and nation building." ${ }^{212}$ Thus, while the reforms during Nasser's era of state-feminism accorded new rights to women in the public sphere, the entrenchment of patriarchy in the private sphere remained an assumption of the Free Officers. This meant that the effects of these reforms were relatively shallow for women.

\section{Political Enfranchisement}

Even though women were provided the right to vote and to hold political office, "Feminists were neither brought into decision-making positions nor consulted about the needs of female constituents." ${ }^{213}$ Precisely because the Free Officers elevated to power through the old, patriarchal, military-elite system, women were excluded from the inner circle of the Nasser regime. Men continued to retain power and exclusively reserved for themselves the role of arbitrating social and political roles for women. Women's suffrage was diluted by “stipulating that though men were required to register, it was optional for women." 214 This meant that fathers and husbands could prevent their daughters and wives from registering. For this reason, voting among women progressed slowly. In 1957, for example, 5.5 million men registered to vote while

${ }^{210}$ Botman, Selma, Engendering Citizenship in Egypt, History and Society of the Modern Middle East Series. New York: Columbia University Press, 1999, 65.

${ }^{211}$ For example, left-leaning women mounted a hunger strike, while more moderate women like journalist, editor, and Nasser-supporter Amina al-Sayyid publicly declared support for women's right to vote. For more, see: Hatem, Mervat, "Nationalist Discourses on Citizenship in Egypt," in Gender and Citizenship in the Middle East. Ed. Joseph, Suad, Syracuse University Press, 2000: 46-47.

212 Botman, 52.

${ }^{213}$ Botman, 52.

${ }^{214}$ Botman, 55. 
only 144,000 women registered. By 1965, that number among women had less-than-doubled to a mere $250,000 .{ }^{215}$ Furthermore, women were forced to petition the state to register, which further disenfranchised poor women, many of whom were illiterate. ${ }^{216}$

The freshly gained right to hold political office might have been an opportunity for feminists to continue legislating new rights and reforms, particularly in matters of family law. In fact, two women were elected to office in the first elections to the National Assembly in $1957 .{ }^{217}$ However, the Nasser regime required any candidates to be vetted by the Liberation Rally. ${ }^{218}$ This meant that any women who challenged the Nasserist regime could be barred from running. For both male and female candidates, those who "prevailed at the polls [did so] not because their ideas appealed to voters, but rather because the state boosted them to victory." 219

When Nasser and the Free Officers banned political parties in Egypt, feminists who had spent the better part of the twentieth century building a female identity in political activism were caught in the crosshairs. Nasser banned feminist magazine Bint al-Nil (Daughters of the Nile) in 1953. ${ }^{220}$ The EFU was forced to abdicate its political activist roots and reorganized as a social welfare organization under the name of the Huda Shaarawi Association. ${ }^{221}$ Outspoken feminists were necessarily ostracized. For example, Saiza Nabarawi, who helped form the EFU, was vocally "critical of the authoritarian tendencies of the military leaders." 222 Feminists of the time were left with the options of either endorsing the Nasser regime, remaining silent, or vocalizing their dissent and, therefore, making themselves the targets of Nasser's tyranny. Thus, Nabarawi's

\footnotetext{
${ }^{215}$ Botman, 55.

${ }^{216}$ Botman, 67.

217 Botman, 55.

${ }^{218}$ Cleveland, 300.

219 Botman, 56.

220 Botman, 65.

${ }^{221}$ Botman, 66.

${ }^{222}$ Botman, 66.
} 
fellow feminists removed her from membership. In this way, Nasser's tyranny often made women "complicit in their own" oppression. ${ }^{223}$

The insight feminists held regarding the intersection that poverty created led to the persecution of feminists who argued against the requirement of women to petition the state to register to vote. The name of Bint al-Nil's founder, Durriyyah Shafiq, was banned from print and she was placed under house arrest in 1960 until her death in $1975 .{ }^{224}$ Even national feminists who mobilized to support the regime were excluded from political activism. For example, a group of feminists organized to provide women paramilitary training during the British invasion of the Suez Canal zone in 1956, but the Nasser regime shut the operation down. ${ }^{225}$

Nasser broke with Egyptian tradition and took to jailing female activists. Zainab alGhazali, who headed the Muslim Women's Society, was arrested in $1965 .{ }^{226}$ In her own testimonies, al-Ghazali recalled incidents where prison guards attempted to rape her. In one case, she bit "the neck of one her attackers until he died." ${ }^{227}$ Nasser and the Free Officers recognized the probability that such a break with tradition would be contentious and censored journalists from reporting the arrests. ${ }^{228}$ Furthermore, women who were arrested were refused rights to visitation by their family in order to prevent them from politicizing their family members. ${ }^{229}$

The inability of feminists to voice dissenting views against the Nasser regime marked a backward step from the liberal-age of the monarchy, despite women's enfranchisement. In the liberal-age, women were remarkable actors in Egyptian national politics. Under Nasser, that role was reserved exclusively for the all-male military bureaucrats. With the all-male bureaucratic

\footnotetext{
${ }^{223}$ Botman, 64.

${ }^{224}$ Botman, 67.

225 Botman, 68.

${ }^{226}$ Botman, 68-69.

${ }^{227}$ Al-Ghazali, Zeinab. Days from My Life. Dar al-Shuruq, 1982, 100-101.

${ }^{228}$ Botman, 68 .

${ }^{229}$ Botman, 68.
} 
regime retaining sole claim over this role, their patriarchal assumptions became embedded in Egyptian identity politics. Patriarchy was no longer a question of confession or class, but a staple to what it meant to be Egyptian. These patriarchal assumptions were observable not only in the private sphere of the family, but in the public sphere where women had new rights to participation through work and education.

\section{Work and Education}

While women made considerable gains in education and work, Nasser's choice to create greater access or women was entirely economic, rather than a commitment to women's rights. ${ }^{230}$ Women's gains were thus curtailed by patriarchal assumptions held by Nasser and the Free Officers. The Egyptian government passed a labor code in 1959 which provided paid maternity leave, paid breaks for new mothers, restrictions against firing expecting or new mothers, and required any company employing over one hundred women to provide child care. ${ }^{231}$ These reforms were remarkable considering some Western states have yet to achieve similar standards even presently. However, the emphasis Nasser made on channeling women into "feminine jobs," such as teaching and clerical positions, maintained gendered division in the workplace. ${ }^{232}$ Positions in the judiciary, in diplomatic relations, and management at the Ministry of Agriculture were reserved for men exclusively. ${ }^{233}$

Bier argues that "the prime beneficiaries of state efforts to increase the size of the female labor force were educated middle-class women" since the bulk of new employment opportunities resulted out of state-building endeavors. ${ }^{234}$ New positions as teachers, doctors, nurses,

\footnotetext{
230 Botman, 59.

${ }^{231}$ Botman, 59. For more, see: Hammam, Mona, "Women and Industrial Work in Egypt: The Chubra El-Kheima Case," in Arab Studies Quarterly 2, no. 1 (1980): 58.

232 Botman, 57.

233 Bier, 66-67.

234 Bier, 66.
} 
pharmacists, civil servants, and social workers all required higher education, which still primarily middle and upper-class women pursued. For this reason, despite state efforts to draw more women into the workforce, "by 1969 , women still composed only about one tenth of the formal wage labor market." ${ }^{, 235}$ Bier writes that information regarding increases in employment for working-class women proves inadequate as many female agricultural workers weren't included in state-ran data collections because their agricultural work was often considered housework, rather than real employment. ${ }^{236}$ This view was further entrenched in legislation which provided for unequal pay to female agricultural workers on the basis that their work was less valuable than that of male agricultural workers. ${ }^{237}$

The patriarchal assumptions made by the Nasser regime were observable through the emergence of gendered narratives regarding female employment. Issues of modesty and etiquette in the workplace, how to negotiate relations with male coworkers and superiors, and even how women should decorate their office became topics of debate in state-ran newspapers and magazines. ${ }^{238}$ Furthermore, the preservation of patriarchal power within the family left femaleworkers with the additional challenge of juggling their familial obligations with their new obligations to the state as economic participants. For example, without reform to male roles within the family, female workers were expected to continue burdening the responsibility of child care alone. Attempts to address this matter were made with the passage of the labor code which required businesses with over one hundred female employees to run day care centers.

\footnotetext{
${ }^{235}$ Bier, 68.

${ }^{236}$ Bier, 67.

${ }^{237}$ Bier, 67.

${ }^{238}$ Bier, 93-100.
} 
However, to skirt around this law, many businesses kept their number of female employees just under the ordinance level. ${ }^{239}$

Educational reforms became a centerpiece to the Nasserist modernization program. Not only was primary education made compulsory for both boys and girls, but education was made tuition free at all levels. ${ }^{240}$ By 1960, school enrollment among girls and women rose to 56 percent, almost 20 percentage points higher than the 1953 figures. ${ }^{241}$ During the Nasser administration "female enrollment in general secondary education increased by an astonishing 631 percent" while "the female population at the university level climbed six-fold." 242 However, even in education, the patriarchal assumptions made by the Nasser leadership could be observed. Women were encouraged to enter educational programs that agreed with gendered norms. Clerical education among women rose 1,750 percent between 1953 and $1971 .{ }^{243}$ Thus, "while government provided various training opportunities and work experiences unavailable before this time, its emphasis on secretarial posts for women betrayed the traditional attitudes of the military leaders." 244

Overall, women made remarkable gains in the public sphere through education and employment. This has led many women to claim that the Nasser period was one of the greatest periods for women's liberation in Egypt. ${ }^{245}$ However, because the all-male military leadership monopolized state power, women still lacked any agency to decide the terms of their liberation for themselves. The Nasser regime lacked any real conviction to reform the patriarchal nature of

\footnotetext{
${ }^{239}$ Bier, 79.

240 Botman, 56.

241 Botman, 56.

242 Botman, 56.

243 Botman, 57.

244 Botman, 57.

${ }^{245}$ Both Bier and Botman offer critiques of this view: Bier, 6; Botman, 51.
} 
the private sphere, so women's dependence on men continued despite advances made for them by the state in the public sphere. ${ }^{246}$

\section{Family Law}

In the private sphere, patriarchal systems were legally enshrined through family law. These systems were assumed inherent to national identity by the Nasserist regime as is evident from the National Charter of 1961, which replaced the 1956 constitution when Egypt and Syria were briefly unified. Article 18 legitimized the patriarchal assumptions of the Free Officers by declaring "that the state was to secure, in accordance with the law, the support of the family and the protection of mothering (al-ummuma) and childhood (al-tufula)." ${ }^{247}$ Furthermore, the charter described the family as the "first cell of society" and asserted its claim over protecting this cell in order to "preserve the national tradition and to reproduce its social fabric." 248 This made the family and its patriarchal structure not only a matter of state interest, but a matter of state regulation. The Egyptian state's resolution to reproduce the "social fabric" of the patriarchal family was a move intended to ingratiate itself with the Egyptian public at large. Providing women new opportunities to education and work was economically necessary; maintaining the patriarchal male order Egyptian society had been built around for centuries, however, was politically necessary.

During this period, Nasser brought the various confessional family courts into a unified system of state courts. Already, the oppressive patriarchal systems within the family instituted by personal status laws were identifiable across confession in Egypt. ${ }^{249}$ Naturally, the unification of

\footnotetext{
${ }^{246}$ Hatem, Mervat, "The Enduring Alliance of Nationalism and Patriarchy in Muslim Personal Status Laws: The Case of Modern Egypt," in Feminist Issues, Spring 1986, 31.

${ }^{247}$ Bier, 110; for more, see: Republic of Egypt, Ministry of Justice, Al-Dustur, Al-Matb'at al-Amiriyya, $1956,11$.

248 Bier, 111; for more, see: United Arab Republic, Charter, 93.

${ }^{249}$ For more, see: Afifi, Mohammed, "Reflections on the Personal Status Laws of Copts," in Women, the Family and Divorce Laws, ed. Sonbol, A., Syracuse University Press, 1996, 202-219.
} 
confessional courts was protested by the various religious orders who felt their autonomy and authority over their respective communities was at threat. Bier writes that Nasser's solution was to "[privilege] the rights of confessional communities to have their family matters adjudicated by their own laws," rather than reform the laws into a universal code. ${ }^{250}$ When state courts began adjudicating family law without reforming it, the patriarchal hierarchy apparent across confession was sanctioned by the Egyptian state. This meant that women's oppression within the family was no longer a tradition according to religion or class, but a tradition according to Egypt itself. Thus, the patriarchal family system was securely embedded into Egyptian identity politics. When Egypt and Syria unified in 1961, Nasser formed a committee to establish universal personal status laws within the vision of Arab Socialism. Still, no serious reforms were made until 1979. ${ }^{251}$ Compulsory enforcement of bayt al ta' $a$ was ended by executive order by the Minister of Justice in 1967. However, it was not removed from family law, but amended. Family law instead dictated that a woman deemed disobedient by the state courts forfeited entitlement to financial support by her husband. ${ }^{252}$ The committee formed under the Nasser administration refused to restrict divorce filed by men in order to protect "family secrets" from public scrutiny. ${ }^{253}$ Bier concludes that family law was never seriously reformed because "the vision of marriage contained within the personal status laws was eminently compatible with the model of family" assumed by the state. ${ }^{254}$

Hatem critiques the theory that feminist struggles in the developing world take an "economic survival" framework by pointing to the Nasserist period of Egyptian society. She argues that, "To assume that the fight against underdevelopment is also a fight against gender

\footnotetext{
250 Bier, 108.

251 Bier, 109.

252 Bier, 119.

253 Bier, 117.

${ }^{254}$ Bier, 120.
} 
inequality simplifies the complexity of patriarchal domination and its capacity to adapt to new conditions. ${ }^{" 255}$ Instead, Hatem writes that the status of women ought to be evaluated from gender definitions and rights. The acceptance by some that the Nasserist era was a golden age for Egyptian women evaluates women's status on a solely economic basis. In fact, the Nasserist state's view that the government needed to replicate the patriarchal structure of the family embedded gender inequality into Egyptian nationalist identity.

This eventually proved dangerous for women. Hatem writes that this led many Egyptians

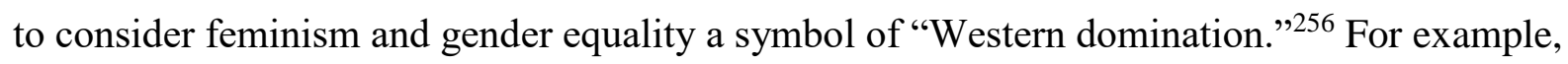
Munira Husni, argued that restricting male divorce was a mark of "European secularism," and an affront to the Egyptian national identity. ${ }^{257}$ Furthermore, it left gendered definitions of roles and rights unaltered. This causes Hatem to argue that Egyptian observers should not have been surprised when, eventually, women were called to leave public employment after Egypt's economy failed to improve..$^{258}$

Botman points to Catherine MacKinnon who argues that, "The law treats women the way men see and behave toward women." ${ }^{259}$ Reversely, the state can change the way men see and behave toward women through law if women's liberation is a true conviction. For the Nasserist state, it wasn't. While nationalist men may have viewed women as agents of modernization, "women continued to be treated as subordinates because the regime did not address personal status law or family relations."260

\footnotetext{
255 Hatem, "The Enduring Alliance," 22.

${ }^{256}$ Hatem, "The Enduring Alliance," 35.

257 Bier, 115.

${ }^{258}$ Hatem, "The Enduring Alliance," 19.

${ }^{259}$ Botman, 70.

${ }^{260}$ Botman, 70.
} 
Inevitably, Nasser's authoritarian grip induced the ire of Egyptian society. When Nasser's military experienced devastating losses to the Israeli army in 1967, reactionary, conservative forces gained traction. These forces declared opposition against all of Nasser's policies, including the few advances that were provided to women such as suffrage, education, and work. The entrenchment of women's oppression and patriarchal power in Egyptian national identity politics deepened as the reactionary conservatives sought a return to tradition. Feminist organizations and political activism had been effectively dismantled over the course of the Nasser regime, leaving them with little ability to mobilize against the reactionary conservatives who aimed to reverse the progress women had achieved over the decades.

\section{Egypt Under Sadat and Mubarak}

When Nasser died in 1970, Vice President Anwar Sadat assumed power. The turbulent political climate surrounding Nasser's death could have presented a power struggle in Egypt. However, Sadat inherited the presidency for two reasons: first, Sadat galvanized the energy of the conservative forces who opposed Nasser in order to vanquish his left-wing political rivals; ${ }^{261}$ second, he commanded an intensive security apparatus that the U.S. described in 1969 as reaching "into almost every corner of Egyptian society."262 Similarly, Hosni Mubarak came into power in 1981 after serving as Vice President under Sadat. The circumstances of Mubarak's rise were no different. A reactionary, conservative uprising in response to economic deterioration and increasingly violent political repression undermined the Sadat regime. Except, this time the uprising resulted in Sadat's assassination.

\footnotetext{
261 Botman, 75.

262 Brownlee, Jason, “Peace Before Freedom: Diplomacy and Repression in Sadat's Egypt," in Political Science Quarterly, 126:4, 2012, 647. For more, see: Sirrs, Owen, History of the Egyptian Intelligence Services, Routlege, 2010, 112-113.
} 
Both Sadat and Mubarak compounded upon the violent repression of Nasser's government. The period of intensified authoritarianism in Egyptian history under Sadat and Mubarak can be attributed to the emerging hegemony of the United States and capitalism during the last chapter of the Cold War. The police state and the military forces of the Sadat and Mubarak regimes were both underpinned by American foreign aid. In return for the aid, Sadat and Mubarak were expected to fulfill their end in the American agenda for the Middle East. The United States not only expressly recognized the violent repression both Sadat and Mubarak exercised, but explicitly exploited it.

Cleveland writes that, "The three pillars of U.S. cold war policy toward the Middle East since the 1950s had been assuring the security and prosperity of Israel, containing Soviet ambitions, and securing access to the petroleum resources of the oil-producing states."263 Nasser's policy of non-alignment coupled with his determination to lead the cause against Israel put a drain on the Egyptian economy. When Sadat entered power, he was mounted with a $\$ 2$ billion deficit and a foreign debt that outsized Egypt's gross domestic product. ${ }^{264}$ Ending the war was economically necessary for the new regime. However, conceding to Israel would put Sadat's already fragile position at risk. Furthermore, Israel would not ratify any peace treaty desirable to Egypt. If Sadat wanted leverage in the conflict, befriending the U.S. was his only hope.

Sadat made an about-face and "expelled 20,000 Soviet military advisers." ${ }^{\text {265 }}$ Sadat then conspired to force a military stalemate that would require the superpowers to intervene with what would be remembered as the October War. Despite expelling Soviet military advisors, Sadat continued to receive Soviet weaponry throughout the war, while America supplied Israel. ${ }^{266} \mathrm{~A}$

\footnotetext{
${ }^{263}$ Cleveland, 500.

${ }^{264}$ Brownlee, 651.

${ }^{265}$ Brownlee, 648.

${ }^{266}$ Cleveland, 366.
} 
ceasefire was declared by the superpowers only after losses amounted to over 13,700 soldiers on either side. ${ }^{267}$ Furthermore, the conflict made a third world war appear imminent when Israeli forces attacked a Soviet merchant ship off the coast of Syria. Soviet warships dispatched to the Mediterranean and were authorized to open fire on Israeli combatants. The carnage made clear one ominous revelation: that both the Soviets and the U.S. were willing to engage directly. ${ }^{268}$ The realization made an Egyptian-Israeli peace agreement more imperative than ever.

After Egypt complied with the U.S.-Soviet brokered ceasefire, then-President Nixon appropriated to Egypt \$250 million in economic assistance. ${ }^{269}$ The aid came with conditions, but it nevertheless initiated a new era of U.S.-Egyptian relations. Following receipt of the endowment, Sadat announced the political and economic liberalization of Egypt. He reversed Nasser's policy of Arab Socialism, “stripped away state intervention, provided major tax exemptions for foreign companies, and lifted the requirement that foreign companies be partly Egyptian-owned." 270 This was a welcomed win for the U.S. who led the capitalist alliance in the Cold War. Consequently, the U.S. ended its arms-embargo against Egypt and American aid inflated to over $\$ 1$ billion annually. ${ }^{271}$

However, the promise of political liberalization was empty. From its inception in 1971, the Sadat regime was heavy-handed against opposition. Sadat purged left-wing political rivals from government. ${ }^{272}$ In order to ingratiate himself with the Egyptian public, Sadat instead appealed to the conservatives who opposed Nasser. ${ }^{273}$ For example, Sadat released conservative

\footnotetext{
${ }^{267}$ Cleveland, 364.

${ }^{268}$ Cleveland, 366.

${ }^{269}$ Brownlee, 648.

${ }^{270}$ Brownlee, 649.

${ }^{271}$ Brownlee, 649.

272 Cleveland, 346.

${ }^{273}$ Hatem, "The Enduring Alliance," 32; Botman, 75.
} 
political prisoners who were arrested during Nasser's regime. ${ }^{274}$ The privatization of the Egyptian economy under Sadat, or infitah, precipitated greater political turbulence. The inflation rate soon rose to over 20 percent, ${ }^{275}$ while Egyptian exports declined. ${ }^{276}$ In 1975 , worker strikes spread across Egypt, beginning in Cairo until "40,000 laborers in the industrial town of Mahalla went on strike."277 Sadat's police state responded with machine guns.

The new policy of infitah made Egypt eligible for international aid from the International Monetary Fund (IMF). However, the IMF's economic aid became a further extension of the neocolonial, capitalist world order. For Egypt particularly, IMF aid was a channel for Western influence in Egyptian policy. For example, in 1977 the IMF informed Sadat that Egypt would not qualify for new loans until they were divested from state welfare and invested in "more productive areas." ${ }^{278}$ Under Mubarak, the IMF continually pressured the Egyptian state to privatize public sectors, an action that was logistically infeasible given the Egyptian people's heavy reliance on government employment. ${ }^{279}$ In exchange for aiding the U.S. in the 1991 Gulf War, the IMF cut Egypt's accumulated debt in half. ${ }^{280}$

Sadat adhered to the IMF's warnings. His “decision to retrench subsidies, rather than curb military spending, debt servicing, or investment, reflected the government's priorities about placating domestic and foreign elites." 281 Inevitably, nationwide riots once again spread. At one

\footnotetext{
${ }^{274}$ Botman, 75.

275 Cleveland, 368.

${ }^{276}$ Brownlee, 650 .

277 Brownlee, 650.

${ }^{278}$ Cleveland, 368.

279 Cleveland, 382.

${ }^{280}$ Lothe, Anders Toft, "Integrity Starts At Home: The International Monetary Fund and the promotion of good governance policies in Egypt between 1996 and 2011," University of Bergen, 2016, 14. For more on the use of the IMF as a U.S. foreign policy vehicle, see: Momani, Bessma, "American politicization of the International Monetary Fund," in Review of International Political Economy, 11:4, 2004, 880-904.

${ }^{281}$ Brownlee, 651.
} 
point, protestors reached upwards of 30,000 in Cairo. ${ }^{282}$ Sadat's security forces eventually quelled the demonstrations, but in so doing arrested between 1,200 and 2,000 Egyptians. ${ }^{283}$ If the protests didn't irrevocably reverse Egypt's trajectory towards liberalization, they certainly cemented Egypt's path towards greater authoritarianism than the country had witnessed ever before. The following day, Sadat took to state-broadcast to propagandize the protests as being the work of Soviet agents. He then promised that from then on, strikes and demonstrations would be criminalized. ${ }^{284}$ Such a promise necessitated a dramatic increase in internal security forces, which prompted Sadat to further entrench the Egyptian state in the U.S.-led capitalist alliance with $\$ 750$ million in military aid. ${ }^{285}$

By alienating his government from the Egyptian people and simultaneously increasing his dependence on U.S. foreign aid, Sadat undermined his diplomatic position. Towards the end of the 1970s, the United States political agenda in the Middle East focused on obtaining a peace agreement between Egypt and Israel. First and foremost, this was due to the U.S.'s operation to gain hegemony in the Middle East. A peace agreement between Egypt and Israel had the potential to completely undo the Soviet strategy. Furthermore, presidential re-elections loomed for then President Jimmy Carter in $1980 .{ }^{286}$ At one point, Carter went as far as warning the Sadat that not reaching a peace agreement would cost him his job. ${ }^{287}$

\footnotetext{
282 Brownlee, 651. For more, see: Baker, Raymond, Egypt's Uncertain Revolution under Nasser and Sadat, Harvard University Press, 1978, 166.

283 Brownlee, 651.

284 Brownlee, 652.

285 Brownlee, 653.

286 Brownlee, 656.

${ }^{287}$ Brownlee, 656. For more, see: Kamel, Mohamed I., The Camp David Accords: A Testimony by Sadat's Foreign Minister, KPI, 1986, 371.
} 
Carter pressured Sadat to compromise on a number of issues by threatening to withdraw U.S. foreign aid to Egypt. ${ }^{288}$ Sadat informed his delegation that he would agree to any proposal made by President Carter at all. ${ }^{289}$ Carter relied on Sadat's heavy hand to force any concessions made in the treaty through Egypt. In his own autobiography, Carter wrote that, "It was obvious that under strong leadership, the opinion of the Egyptians could be changed." 290 Sadat and Carter met to discuss a peace treaty between Egypt and Israel just months after Sadat's security forces had violently repressed nationwide riots. The same month a peace treaty was reached, the State Department awarded U.S. company Jonas Aircraft and Arms a license to sell the Egyptian government 100,000 tear and pepper gas grenades. ${ }^{291}$ Their use on Egyptians was inevitable. The U.S. not only exploited Sadat's violent repression of the Egyptian people but enabled, encouraged, and relied on it as a political strategy.

Following the ratification of the peace treaty, Egypt received an annual aid package of approximately $\$ 1$ billion from the U.S. government. ${ }^{292}$ Consequently, Egypt was expelled from the Arab League and lost subsidies from the oil-producing states in the Middle East. ${ }^{293}$ Effectively, Egypt's economic dependence on the U.S. deepened, which enabled the U.S. to bend Egypt to its will. Critics pointed out that "the specific projects funded by U.S. economic assistance and the methods by which they were selected" made it appear "that U.S. priorities, not Egyptian ones, were driving Egypt's development strategy."294 Western nations no longer required direct imperialism to force their interests through foreign nations. Providing military and economic aid to dictators who would otherwise be overthrown was effective enough.

\footnotetext{
288 Brownlee, 655 and 659.

289 In fact, Sadat would sign any proposal "without reading it;" Brownlee, 657; and Kamel, 357.

290 Carter, Jimmy, Keeping the Faith: Memoirs of a President, Bantam, 1982, 410.

291 Klare, Michael T., Supplying Repression, Field Foundation, 1977, 144-145.

292 Brownlee, 662.

293 Cleveland, 370.

294 Cleveland, 383.
} 
This transformation of foreign influence had dire consequences for Egyptians who demanded political freedom. When members of the Egyptian parliament objected to the peace treaty, Sadat disbanded parliament and called for new elections. Only two of the former parliament members who objected to the treaty were reelected, including Mumtaz Nasr, "whose supporters brandished submachine guns and forced the police to count ballots on the spot."295 Thanks to the neocolonial capitalism world order, any vestige of democracy in Egypt necessarily turned militant. Sadat also increased levels of surveillance and by the end of his run in office he had imprisoned over 1,500 activists, including women's liberation advocate Nawal elSaadawi. ${ }^{296}$ When Sadat first came to power, he rejected Nasser's secularism and galvanized conservative religious fervor to undermine the appeal of Nasser's socialist policies. ${ }^{297}$ Over time, opposition from religious groups increased, which led Sadat to reverse course and arrest Islamic activists. A brother of an arrested activist assassinated Sadat in 1981, giving rise to Mubarak. ${ }^{298}$ Mubarak's run as president of Egypt produced nothing remarkably different from Sadat's regime. Instead, Mubarak's government seemed content with preserving the status quo. Mubarak lacked any political agenda or ideology, other than "to stay in power." 299 During his reign in the 1980s, U.S. aid totaled \$2.2 billion annually. ${ }^{300}$ Briefly, in the elections of 1984, Mubarak allowed "the appearance of a new era of political freedom" by permitting the Wafd Party to run in the elections. ${ }^{301}$ However, when the Wafd party gained control of parliament in those elections, Mubarak reversed this liberalization and recommitted the Egyptian state to despotism.

\footnotetext{
295 Brownlee, 661.

296 Brownlee, 664.

${ }^{297}$ Hatem, Mervat, "The Enduring Alliance of Nationalism and Patriarchy in Muslim Personal Status Laws: The Case of Modern Egypt” in Feminist Issues, Spring 1986, 32.

298 Brownlee, 664.

299 Cleveland, 382.

300 Cleveland, 383.

301 Cleveland, 382.
} 
At the same time, capitalism was systematically failing the Egyptian people and U.S. assistance failed to alleviate the country's financial situation and, in fact, dramatically increased economic disparity. Cleveland writes, "Those who did profit from the economic liberalization, many of whom were the president's friends and relatives, engaged in ostentatious displays of wealth that only served to remind the majority of Egyptians how unsatisfactory their own circumstances were." ${ }^{302}$ The globalization of gross economic disparity resulted out of the globalization of capitalism by the neocolonial world order. Its symptoms would not be contained to Egypt alone. Mubarak's regime was forced to abdicate in 2011 by the Arab Spring, a revolutionary uprising that arguably inspired the Occupy encampments that same year.

\section{Women Under Sadat and Mubarak}

Women suffered drastically under the economic deterioration and political repression of the Sadat and Mubarak regimes. Sadat dealt a grave blow to women by manipulating reactionary social conservatism to his advantage prior to repealing Nasser's socialist reforms. The failure of Nasser's government to resolve Egypt's economy and position in world politics beckoned a call to revive cultural authenticity. ${ }^{303}$ In her essay, "Women and the Poor: The Challenges to Global Justice," el-Saadawi explains the emergence of reactionary conservativism in the face of globalization:

"The globalization needed by the international capitalist system leads people in different countries or cultures to resist homogenization resulting from the global culture, or so-called universal values. It is a self-defence mechanism. It is an attempt to hold on to an authentic identity, or authentic culture or heritage, and these are some of the factors in the growth of religious fundamentalism, racism and ethnic struggles. It is a protest movement (especially among the youth), but very often takes on reactionary, retrograde, anti-women and antiprogressive characteristics, leading to division and discord; it thus serves the purpose of capitalist globalization because it divides the people who are resisting it."304

\footnotetext{
302 Cleveland, 370.

303 Botman, 76.

${ }^{304}$ El-Saadawi, Nawal, "Women and the Poor: The Challenge of Global Justice," in The Essential Nawal El Saadawi: A Reader, ed. Newson-Horst, Adele, Zed Books, 2010, 88.
} 
For social conservatives, cultural authenticity included the older generation's framework for women's citizenship that Nasser altered by opening public sector employment to women. Sadat attempted to assimilate these social conservatives into his cadre of supporters by the passage of a new constitution in 1971 . The constitution pledged that the family was a unit shaped by national values and that the state would "preserve this genuine character of the Egyptian family" by supporting for women's work only when it did not interfere with the family. ${ }^{305}$ This effectively vested the patriarchal male order instituted in government, in private business enterprises, and in the family with the renewed power to "dislodge women from their previous gains." ${ }^{306}$ Patriarchists asserted that in a stagnating economy, women were obligated to return home and relinquish their positions to men. ${ }^{307}$

Sadat's economic policies quickly resulted in increasing wealth gaps between the poor and the bureaucratic elite. The structural adjustment policies of the IMF not only included reducing government spending in order to favor debt repayments, but privatizing trade, reducing barriers to foreign investment such as tariffs and import duties, and increasing interest rates which, in turn, reduced the ability of Egyptians to obtain credit. ${ }^{308}$ While the wider Egyptian population struggled to find employment, went hungry, and lost access to important services such as medical care, the elite under Sadat's rule flourished. Displays of wealth only augmented the resentment and frustration of Egypt at-large. In fact, Sadat's own displays of wealth became so obtuse that Egyptians called him "Faruq II."309

\footnotetext{
${ }^{305}$ Hatem, "The Enduring Alliance," 32.

${ }^{306}$ Botman, 79.

${ }^{307}$ Hatem, "The Enduring Alliance," 35.

${ }^{308}$ Ismi, Asad, Impoverishing a Continent: The World Bank and the IMF in Africa, Hallifax Coalition Initiative, 2004,5 .

${ }^{309}$ Cleveland, 370.
} 
Thus, the new class of Egyptian wealthy became "symbols of a new wave of Western cultural and economic domination." ${ }^{310}$ El-Saadawi echoes this view: "Development is just another word for neocolonialism." ${ }^{311}$ The structural adjustments Sadat pursued under the influence of the US and the IMF impacted women the hardest. As the state cut its contributions to services for Egyptians, "women, who were heavily dependent on the state for employment and services, found fewer opportunities in the paid labor force and faced a truncated social welfare network." ${ }^{312}$ Lack of new job opportunities meant greater competition for work, which caused women's employment to come under fire. The social tensions created by such economic pressure resulted in an increase of women's harassment. ${ }^{313}$ Yet the structural adjustments made in Egypt dramatically raised living costs and inflation, which meant women couldn't afford to forfeit their jobs. Furthermore, the political repression asserted by Sadat left working-class Egyptians little recourse to improve their lots democratically.

The hard-hitting economic consequences felt by women due to Sadat's capitalist policies caused anti-capitalism to become a central part of Egyptian feminist politics. Anti-capitalism is such a prominent factor in the politics of el-Saadawi, that she even cautions against terming herself a "feminist," precisely because the language of feminism was created by the capitalist West. In Egypt, to be a feminist is to be anti-capitalist and anti-colonialist, as well as antipatriarchist. The politics of the capitalist world order at once purport to support freedom and democracy, but "but whose agreements and decisions lead to the opposite - that is, to war, poverty, inequality and dictatorship." ${ }^{\prime 314}$ Women are most impacted by the economic inequalities initiated by capitalism. Between the 1970s and 1980s, poverty among women in the world rose

\footnotetext{
${ }^{310}$ Hatem, "The Enduring Alliance," 33.

311 El-Saadawi, "Women and the Poor," 80.

312 Botman, 78.

${ }^{313}$ Hatem, "The Enduring Alliance," 34.

${ }^{314}$ El-Saadawi, "Women and the Poor," 78.
} 
by fifty percent and, even though women worked two-thirds of the total labor hours recorded by UN figures, they earned only "one-tenth of total world income." ${ }^{315}$ For that reason, el-Saadawi argues that inherent to global gender justice is the reorganization of "a new world order based on justice." ${ }^{316}$ El-Saadawi's positions on economic justice would be rearticulated by both the Egyptian Arab Spring in 2011, as well as the Occupy Wall Street movements that same year.

When social conservatives turned on Sadat, he attempted to reverse course with respect to women and women's rights. Sadat broke Egyptian tradition and inserted the Egyptian state into the private sphere of the patriarchal family by reforming Egypt's personal status codes. The new laws regulated polygamy by allowing wives to divorce their husbands if they did not agree to the polygamous arrangement, while ensuring that a divorced mother would not be penalized for doing so by being evicted from her home. ${ }^{317}$ However, because the reforms were passed through an executive decree, both conservatives and feminists protested the authoritarian hand with which the laws were instituted. ${ }^{318}$

Following Sadat's assassination, the High Constitutional Court determined the laws to be unconstitutional on the grounds that executive decrees could be issued only in states of emergency. ${ }^{319}$ Similarly, Sadat issued another executive decree in 1979 which reserved thirty seats in the Egyptian parliament for women and stipulated that "10 to 20 percent of the seats in the twenty-six government councils around the country be signed to women." ${ }^{2320}$ Once again, while the policy might have been something that earlier feminists would have endorsed, they

\footnotetext{
${ }^{315}$ El-Saadawi, "Women and the Poor," 83.

${ }^{316}$ El-Saadawi, "Women and the Poor," 80.

${ }^{317}$ Hatem, "The Enduring Alliance," 37.

${ }^{318}$ Botman, 84-85.

${ }^{319}$ Hatem, "The Enduring Alliance," 37.

${ }^{320}$ Botman, 82.
} 
could not accept his authoritarian style. ${ }^{321}$ When Sadat's reforms failed to win over Egyptian women and, instead, stirred even more, his regime passed the "Law of Shame." Purportedly, the law was designed to protect Egyptian values. In reality, it was used to imprison opponents before a special court without ability to appeal the verdict of the court. ${ }^{322}$ Both liberal and conservative women alike, including el-Saadawi, were imprisoned under the Law of Shame. ${ }^{323}$

Mubarak's rise to power continued the Sadat regime's authoritarianism through the implementation of the Law of Shame while simultaneously appeasing ultra-conservatives by repealing the reforms Sadat passed to advance women's status. The Arab Women's Solidarity Association (AWSA) produced a journal titled Nun and wrote about a range of controversial subjects such as family life, marriage, female circumcision, and poverty. The Mubarak regime eventually forced the journal to stop publication. The next year, after the AWSA spoke out against Mubarak's support of the Gulf War, the regime forced the AWSA to disband altogether using Sadat's Law of Shame. ${ }^{324}$ In 1986, Mubarak replaced Sadat's 1979 representation quotas with a law that provided for each "geographic constituency" a single seat "to an independent candidate, without regard to gender." 325 As a result of Mubarak's abolishment of the quota system, only 10 women held office in Egyptian parliament by 1990, and only 7 of those had been elected while 3 were appointed. ${ }^{326}$

\footnotetext{
321 Botman, 83 .

322 Botman, 88 .

${ }^{323}$ El-Saadawi was imprisoned in 1981 without trial for criticizing Sadat's one-party rule. El-Saadawi was also fired from an Egyptian publication for being the first woman to write against female circumcision in 1969 and was exiled to the United States in 1993 for writing against the Gulf War. For more on her illustrious life as a writer and activist, see: Saadawi, Nawal El. Walking through Fire: The Later Years of Nawal El Saadawi. Trans. Hetata, Sherif. Zed Books Ltd., 2013.

${ }^{324}$ Botman, 93-94.

${ }^{325}$ Botman, 90.

${ }^{326}$ Botman, 91 .
} 
The decades under Sadat and Mubarak were difficult and divisive for all of Egypt, but especially for women. Egyptians who challenged the regime at all were silenced and Egyptian women who challenged the regime on feminist grounds were silenced by both the regimes, and patriarchists. However, one interesting development occurred during these regimes: with a globalized marketplace, came globalized information. The Egyptian women's press harnessed this development by bringing international awareness to women's plight in Egypt. For example, Nun published articles about "the exploitation of poor women and minor girls who were being married to affluent men from Arab oil-producing countries through paid business agents. ${ }^{\prime 327}$ In response, the Egyptian government passed laws regulating these types of arrangements. ${ }^{328}$ Additionally, when the Sadat government began to incarcerate outspoken feminists, globalized access to that information precipitated international letter writing campaigns to support the release of women political prisoners. ${ }^{329}$

The international attention Egypt drew for its treatment of women escalated under Mubarak. At the behest of several international NGOs, Mubarak's regime adopted a so-called "gender agenda." ${ }^{330}$ For example, in 2009, the Egyptian People's Assembly passed a law which created 64 new seats reserved for women. However, a lack of free and open democracy meant that those seats were filled by women affiliated with Mubarak's ruling party, so that "increased women's representation served the interests of the regime." ${ }^{331}$ Though important family laws were reformed, such as establishing a minimum marriage age of 18 and criminalizing female

\footnotetext{
327 Botman, 94.

328 Botman, 94.

329 Botman, 89.

330 Professor of Political Science at the American University in Cairo, Mariz Tadros, defines gender agenda as "political projects of how power relations between men and women should be organized in politics and society." For more, see: Tadros, Mariz, "The Politics of Mobilising for Gender Justice in Egypt from Mubarak to Morsi and Beyond," in Institute of Development Studies Working Papers, 2014, no. 442: 1-35.

331 Tadros, 10.
} 
genital mutilation, ${ }^{332}$ their passage through the Mubarak government provided the appearance that feminism was complicit in the violent political repression of the regime.

These NGOs failed to challenge altogether Mubarak's repressive government and the international financing organizations which kept him in power. By ignoring this global intersection, and instead focusing on women's rights alone, the international women's community in fact increased backlash against women in Egypt. Professor Marzi Tadros writes, "Authoritarianism is not necessarily inimical to women's rights, as long as these rights do not challenge the power base of the status quo in fundamental ways." Rather than improving the lot of Egyptian women, international NGOs legitimized Mubarak's attempts to paint his regime as one "committed to democracy." "333

Regardless, Egyptian feminists demonstrated an admirable prescience of the world's course once more. Under Sadat and Mubarak, Egyptian feminists harnessed the power of globalized information to communicate their cause to empathetic audiences around the world. El-Saadawi articulated this feminist prescience in her essay that was published in the mid-1990s:

"We need unity and solidarity between men and women who resist this global injustice at the local level as well as at the international level. But we need a movement that is progressive, not backward, which seeks unity in diversity [...] This requires establishing a network step by step from the local up to the global level to face the international capitalist network. We can use modern technology such as videos, cassettes, public radio, television, and so on."334

The Arab Spring and Occupy Wall Street movements met el-Saadawi's call to action and mobilized the social assets of modern technology in a revolutionary uprising that swept the world over in 2011.

332 Tadros, 10.

333 Tadros, 11.

${ }^{334}$ El-Saadawi, "Women and the Poor," 88. 


\section{The 2011 Arab Spring and Beyond}

Mubarak was forced to abdicate power in 2011 by a popular uprising known as the Arab Spring. Opposition to Mubarak mounted for three decades prior to the mass demonstrations. The impact of structural adjustments in Egypt caused rampant unemployment, with youth unemployment hitting 25 percent by $2009 .{ }^{335}$ The withdrawal of the Egyptian state from funding needed services such as health-care and food subsidies simultaneously placed a higher burden on families who had less resources to draw from. ${ }^{336}$ In order to stifle dissent, the Mubarak regime weaponized the Egyptian bureaucracy in order to rescind or refuse permits to universities, mosques, and media outlets for expressing political views that ran counter to the state. ${ }^{337}$

Elections under Mubarak were characteristically fraudulent and marred by corruption. In 2005, the Egyptian state refused to accept ballot counts which gave a Brotherhood-affiliated candidate a seat in parliament and instead awarded the seat to the candidate's rival. Consequently, riot police tear-gassed hundreds of protesters. ${ }^{338}$

The economic duress and divisive political climate came to a head when a 28 -year old Egyptian man was beaten to death by police after "he had taken pictures of them sharing the spoils of a drug bust." ${ }^{, 39}$ Outrage spread when a video of the man's body revealed that the police had fabricated their report that he died from ingesting drugs. On January 25, 2011, Egyptians took to Tahrir Square to demand Mubarak's resignation, free and fair elections, and the creation of a new Egyptian constitution. Mubarak abdicated his power promptly, less than three weeks

\footnotetext{
${ }^{335}$ Dhillon, N., Dyer, P., \& Yousef, T. "Generation in waiting: An overview of the school to work and family formation transitions, in Generation in Waiting: The Unfulfilled Promise of Young People in the Middle East, ed. Dhillon, N. \& Yousef, T., Brookings Institution Press, 2009, 20.

${ }^{336}$ Hatem, Mervat, "The Arab Spring Meets the Occupy Wall Street Movement: Examples of Changing Definitions of Citizenship in a Global World," in Journal of Civil Society, 8:4, 2012, 406.

${ }^{337}$ Shenker, Jack, "Egyptian elections: independents fight for hearts and minds in 'fixed ballot"' in The Guardian, November 22, 2010.

${ }^{338}$ Shenker, 2010.

${ }^{339}$ Hatem, "The Arab Spring," 408.
} 
after the protests began. However, Mubarak's resignation was forced by the Egyptian military as a strategy to preserve its power. ${ }^{340}$ The Supreme Command of the Armed Forces stepped in as the interim leader of Egypt until free elections could be held.

In her comparative essay on the Arab Spring and the Occupy Wall Street protests, Hatem illustrates the ways in which the neoliberal economic policies of the capitalist world order led to mass demonstrations around the world. The strategic adjustments instituted in Egypt by the IMF were modeled after the same policies that Ronald Reagan initiated in the US and Margaret Thatcher initiated in the UK. ${ }^{341}$ The same policies of reducing welfare and deregulating the economy that eroded Egypt's economy, led to the massive redistribution of wealth from working and middle-class families to the top 1 percent in America - a major point of contention for the Occupy movement that was articulated in its slogan, "We Are the $99 \%$." 342

Like Mubarak, who used the threat of political Islam to transform Egypt into a national security state, the Bush Jr. administration used the so-called war on terror to transform the US into a national security state and provide new legal and extra-legal powers to the executive branch. ${ }^{343}$ This included "new unmonitored powers given to law enforcement agencies [...] including the large-scale surveillance of groups engaged in dissenting activities like the defence of civil liberties, environmental justice, and civil rights." ${ }^{344}$ Hatem's analysis provides important insight: We live in an age of a totally globalized, capitalist world order, whose victims are no longer contained to the "Second" and "Third World." In fact, the citizens of the U.S., the very nation that so aggressively installed this world order, are now experiencing the same consequences of its capitalist policies that others around the world have experienced for decades.

\footnotetext{
340 Ottaway, Marina \& Ottaway, David, “Egypt's Durable Arab Spring,” in Foreign Affairs, January 24, 2016.

${ }^{341}$ Hatem, "The Arab Spring," 405.

342 Hatem, "The Arab Spring," 405.

${ }^{343}$ Hatem, "The Arab Spring," 411-12.

344 Hatem, "The Arab Spring," 412.
} 
The Occupy protests began in September 2011, months after the Arab Spring. Hatem writes that the Occupy protests utilized many of the same tactics Egyptians used in January of the same year, such as making calls to action on social media and protesting through "peaceful public encampment." ${ }^{\prime 345}$ Furthermore, the police which evicted the Occupy encampments used similar strategies that the Egyptian police used in Tahrir Square, such as "attacking the protesters at night, suspending Internet service during the attacks, and describing the protesters of having been infiltrated by criminal elements." 346 The Arab Spring and Occupy protests were both demonstrations against the neocolonial, capitalist world order. That the points of contention for both movements persist today attests to the strength with which this world order has integrated itself with national and international governments. Hatem describes the order as "decentered and deterritorial," able to reproduce "key social actors and their consciousness" in nearly every region of the world. ${ }^{347}$

The first elections held in Egypt following Mubarak’s removal elevated Brotherhoodaffiliated Mohamed Morsi to presidency in June 2012. President Morsi was considered Egypt's first democratically elected leader in history. ${ }^{348}$ Following the elections, Morsi and the newly elected Egyptian parliament drafted an Egyptian constitution that was enacted in December 2012. Despite widespread concerns that a Brotherhood-affiliated candidate would negatively impact women's rights, the 2012 constitution was the first to unequivocally provide "equality and equal opportunities for all citizens, men and women, without distinction, favoritism, or partiality, in rights or duties." ${ }^{349}$ It was the first Egyptian constitution which did not differentiate

\footnotetext{
${ }^{345}$ Hatem, "The Arab Spring," 412-13.

${ }^{346}$ Hatem, "The Arab Spring," 413.

${ }^{347}$ Hatem, "The Arab Spring," 403.

${ }^{348}$ Kirkpatrick, David, "International Observers Find Egypt's Presidential Election Fell Short of Standards," in The New York Times, May 29, 2014.

${ }^{349}$ Egyptian Constitution, Preamble, 2012.
} 
rights or duties of citizens between genders. Furthermore, sentiments of equal citizenship were reiterated five times in Articles 6, 8, 9, 33, and 63, while Article 68 committed the state to take "all measures to establish equality between women and men in political, cultural, economic and social life and all other fields." ${ }^{" 350}$

Less than a year after his election, Morsi was deposed by the Egyptian military under the lead of the Minister of Defense, Abdel Fattah el-Sisi. Sisi subsequently suspended the Egyptian Constitution of 2012 and proposed an election for a new constitution, new parliament, and a new president. ${ }^{351}$ Popular protests spread once again, which the military responded to with the August 2013 Rabba massacre. Human Rights Watch reported that at least 817 people died in the massacre, though it estimated the actual number to exceed 1,000 deaths, while an estimated 4,000 were injured. ${ }^{352}$ The removal of Morsi from power inaugurated a new period of greater authoritarianism and corruption than Egypt has witnessed ever before.

The Egyptian military held elections in 2014, the results of which have been widely disputed. The New York Times reported that international observers, like Democracy International, called fair and democratic elections impossible in Egypt. ${ }^{353}$ That Sisi won the vote by over 95 percent only compounded claims that his election was fraudulent. The election was also characterized by empty polling stations and a remarkable "absence of voters." ${ }^{354}$ Despite this, "roughly 54 million eligible voters had cast ballots" in the 2014 election, giving Sisi 23.9 million votes compared to Morsi's 13.2 million votes in 2012.355

\footnotetext{
${ }^{350}$ Egyptian Constitution, Article 68, 2012.

351 Ottways, 2016.

352 Human Rights Watch, "All According to Plan," hrw.org, August 17th, 2013, retrieved July 20, 2017.

${ }^{353}$ Kirkpatrick, "International Observers."

${ }^{354}$ Kirkpatrick, "International Observers."

${ }^{355}$ Kirkpatrick, "International Observers."
} 
From 2013 to 2015, "at least 1,800 civilians and 700 security personnel [had] been killed, tens of thousands [had] been imprisoned, and severe restrictions [had] been placed on media, civil society, and protest activity." ${ }^{356}$ As the five year anniversary of the Arab Spring approached in 2016, the Egyptian military forcibly searched over 5,000 civilian homes, cracked down on Facebook by blocking access to nearly 3 million Egyptians, and took advantage of the state's control of religious institutions to instruct that all imams warn Egyptian mosque-goers that participating in demonstrations violated Islamic law. ${ }^{357}$

Sisi is up for reelection in 2018. In preparation, the Sisi regime has passed legislation which restricts the ability of human rights organizations to conduct aid within the state. ${ }^{358}$ Despite objections from the international community, Sisi has been "emboldened by a burgeoning friendship with President Trump, who has [...] indicated that he did not intend to allow human rights issues to sour their relationship." ${ }^{359}$ Consequently, Sisi passed the aid restrictions and has continued to ramp up censorship of news media in Egypt. Trump's willingness to overlook Sisi's violence, however, is not new. Under the Obama administration, the US continued to provide military aid to Egypt to the sum of $\$ 6.5$ billion, even following Sisi's seize of power. ${ }^{360}$ In 2016, Sisi won a bid for a $\$ 12$ billion loan from the IMF. ${ }^{361}$ The continuing financial support by the U.S. and the IMF has perpetuated the political tyranny

\footnotetext{
${ }^{356}$ Trager, Eric, "Egypt's Durable Misery," in Foreign Affairs, July 21, 2015.

357 Ottoway, "Egypt's Durable Arab Spring."

${ }^{358}$ Walsh, Declan, "Egypt's President Enacts Law Placing Severe Restrictions on Aid Groups," in The New York Times, May 29, 2017.

${ }^{359}$ Walsh, "Egypt's President."

${ }^{360}$ Pecquet, Julian, "What Happened to the Billions the US Gave to Egypt?" in al-Monitor, May 12, 2016. Article was republished by US News and World Report on May 13, 2016.

${ }^{361}$ El-Badrawi, Mahinour \& Corkery, Allison, "Egypt's New IMF Deal Comes with a Huge Price Tag for Human Rights," Center for Economic and Social Rights, February 9, 2017.
} 
Egyptians fought against in 2011. Thus, the capitalist world order threatens to sweep the revolutionary uprising into the dustbins of history.

\section{Women in the Arab Spring and Beyond}

In 2011, women rose against the Mubarak regime alongside their male counterparts. Female activists like Nawara Negm played a large role in organizing the Egyptian Revolution through online blogging and social media. ${ }^{362}$ Pockets of gendered violence were widely reported upon by the state-ran and foreign medias to stir fear and encourage Egyptians to return home and reinstate law and order. CNN, for example, reported on the gang rape of American journalist Lara Logan and wrote, "One of the hallmarks of revolutionary victory in Tahrir Square has always been rape and sexual harassment." ${ }^{363}$ While gendered sexual violence certainly problematized the participation of women in the revolution, narratives surrounding gendered violence simplify the matter as an issue of religious fundamentalism. Rather than recognizing the global intersection which produced the appearance of complicity on the part of feminism, CNN attributed gendered violence to the Muslim Brotherhood. "Out went the nongovernmental organizations that worked to make divorce easier and inheritance laws fairer. In came the thugs who stripped and beat women in the streets," it reported. ${ }^{364}$ The failure to recognize global intersections thus not only perpetuates women's oppression, but Islamophobia.

In fact, the activism of Egypt's youth during and after the Arab Spring provided a new chapter for women's liberation. A multitude of organizations against women's harassment and assault proliferated in Egypt during and after the revolution. Women's harassment and assault is

\footnotetext{
362 Nawara Negm, for example, posted a blog article and YouTube video encouraging Egyptians to protest on January 25. For more, see: Eltantawy, Nathan \& Weist, Julie, "Social Media in the Egyptian Revolution," in International Journal of Communications, Vol. 5, 2011: 1214.

${ }^{363}$ Burleigh, Nina, “Gang Rapes, the Dark Side of Egypt's Protests.” CNN. July 3, 2013. Accessed March 22, 2018. https://www.cnn.com/2013/07/03/opinion/burleigh-rapes-tahrir-square/index.html.

${ }^{364}$ Burleigh, "Gang rapes."
} 
extensive in Egypt, as it is in most places. A UN study published in 2013 discovered that 99 percent of the 2,000 girls polled had experienced either verbal or physical sexual harassment. ${ }^{365}$ One month prior to the Egyptian uprising in 2011, an organization called Harassmap formed in order "to encourage doormen, shop owners, and others consistently on the streets to intervene if they witnessed harassment." 366 Other groups like Basma, Didd al-Taharrush (Against Harassment), and Shuft Taharrush (I Saw Harassment) have since formed to provide harassmentfree transportation for women, to patrol areas that have "historically facilitated harassment," and to assist victims of assault in seeking justice. ${ }^{367}$ This activism has been widely covered in Egyptian media and TV talk-shows, including Misr 25, a now-canceled Muslim Brotherhood channel. $^{368}$

Anti-harassment and anti-assault activism have led to measurable progress. For example, Cairo University adopted anti-harassment policies after its president was lambasted for criticizing a female student's inappropriate dress after a video of her assault went viral. ${ }^{369}$ Furthermore, the policies adopted by the university were formulated by feminist activists and professors and included an investigatory committee composed of a female-majority. ${ }^{370}$ In 2014 , the Ministry of Health "ordered that hospital emergency rooms would admit all [survivors] and provide them care free of charge for forty-eight hours" after activists called upon the ministry to take action when a female survivor had been denied care. ${ }^{371}$

\footnotetext{
${ }^{365}$ Langohr, Vicki, “After the 'Spring': New Patterns of Grassroots Politics?” in International Journal of Middle East Studies, 47, 2015, 131.

${ }^{366}$ Langohr, 131.

${ }^{367}$ Langohr, 132.

${ }^{368}$ Langohr, 132.

${ }^{369}$ Langohr, 132-133.

${ }^{370}$ Langohr, 133.

${ }^{371}$ Langohr, 133.
} 
Sisi's dictatorship has left women worse off than ever before, though the 2014 Egyptian constitution purports to provide a wealth of economic and political rights to women. Article 11, for example, declares that the Egyptian state is responsible for securing "equality between women and men in all civil, political, economic, social, and cultural rights." ${ }^{372}$ However, the idea that any Egyptians have a shred of genuine political rights to democratic participation under Sisi's regime is laughable at best. Only for this reason, could one justify that women and men are politically equal. Furthermore, Article 11 also articulates that the state must enable "women to strike a balance between family duties and work requirements." ${ }^{373}$ The enmeshment of the private, patriarchal system of the family into Egyptian national identity politics remains.

With Sisi's decision to increase restrictions on the operations of aid organizations and to persecute the individuals involved with them, the consequences for women in Egypt will be harsh. According to a labor study conducted in 2014, women's unemployment in Egypt is double that of men, which consequently makes them an especially large audience to the education, food, and health care services provided by aid organizations. ${ }^{374}$ Worst of all, the International Federation for Human Rights reported in 2015 that the Egyptian state has taken to using sexual violence to diffuse opposition. ${ }^{375}$ The study alleges that members of the police, National Security Intelligence, and the military have all taken part in sexual torture, rape, and sexual blackmail. Sisi's dictatorship has only multiplied crimes against human rights, democracy, and women. Yet, despite Sisi's escalation of political violence, he continues to receive support from the IMF and the U.S. To be clear, Sisi's commitment to becoming one of the most notorious dictators in Egyptian history is made possible only by this financial support.

\footnotetext{
372 Egyptian Constitution, Article 11, 2014.

${ }^{373}$ Egyptian Constitution, Article 11, 2014.

${ }^{374}$ Mounir, Safiaa, "Will new Egyptian employment law help women lean in?" al-Monitor, November 3, 2015.

375 For more, see: "Exposing State Hypocrisy: Sexual Violence by Security Forces in Egypt," International Federation for Human Rights Special Report, May 19, 2015.
} 


\section{Conclusion}

The role of influence Western governments exercise over Egypt has transformed over the last century, but its objectives remain the same. The use of foreign capital by Western governments and international finance organizations to achieve their political and economic agendas has a very real price for Egyptian people and, especially, for Egyptian women. In a world Western hegemonic powers portray as "post-colonial," the domination, violence, and exploitation of the colonial world persists through the capitalist world order. This world order continues to hold in contempt the basic humanity of people around the world, all in the name of free market and profit. The ills of this world order are not contained to Egypt alone. Economic inequality, political tyranny, and national discord have sowed the world over. The impacts of these ills on people generally, but women especially, can no longer be ignored by those who would boast themselves as feminists.

In the words of Crenshaw herself, "When one discourse fails to acknowledge the significance of the other, the power relations that each attempts to challenge are strengthened."376 Without understanding this global intersection, women's rights advocates will continue to fail in their strategies for improving the status of women around the world. In the case of Egypt, international women's advocates and NGOs have opted to work with dictatorships to improve the treatment of women. Because those feminists failed to acknowledge the role of international finance organizations and foreign powers in keeping violent authoritarians in power, they strengthened the gendered violence and discrimination faced by Egyptian women. This is a pattern that must be stopped if Western feminists are to make a sincere effort at cultivating international sisterhood and solidarity.

\footnotetext{
${ }^{376}$ Crenshaw, Kimberle, "Mapping the Margins: Intersectionality, Identity Politics, and and Violence Against Women of Color," in Stanford Law Review, 43:6, July 1991, 1282.
} 
It's imperative that an understanding of global intersections be integrated into the strategies of feminists. El-Saadawi writes, "We cannot speak about global injustice without speaking about inequality between countries, inequality between classes in each country, and inequalities are linked together in the patriarchal capitalist system that governs the world today." 377 The role Western governments have played in propping up repressive regimes is a crime against human rights, and especially women's rights. Without taking this history into consideration, the economic disintegration and violent political repression that has hindered Egyptian women from fully liberating themselves will only continue.

It is time for Western women to abandon not only white feminism, but imperial feminism. They must look to feminists around the world, like el-Saadawi and her Egyptian feminist ancestors, who can provide understanding on the transnational complexities that affect the lives of women around the word. By doing so, feminists can find new inspiration to come together in a truly inclusive, global movement for women's liberation. Patriarchal systems manifested the ideologies which justified colonization and, now, capitalism. Patriarchal systems spread institutions vested with the object of domination and exploitation around the globe. Patriarchal systems created the world of today - a world rampant with poverty, hunger, war, political tyranny, and disease. It is time for all feminists to come together and forge the world of the future, a world in which the many ills of patriarchy are answered. Though feminists may face an uphill battle, they must persist. Globally inclusive, intersectional feminism can show the way.

${ }^{377}$ El-Saadawi, "Women and the Poor," 79. 